\title{
The EU Sustainable Finance Agenda: Developing Governance for Double Materiality in Sustainability Metrics
}

\author{
Iris $\mathrm{H}-\mathrm{Y} \mathrm{Chiu}^{1}$
}

Accepted: 13 December 2021 / Published online: 31 January 2022

(c) The Author(s) 2022

\begin{abstract}
This article argues that the regulatory steers in the recent EU Sustainable Disclosure and Taxonomy Regulations rely heavily on the outworking of market-based governance to meet public interest goals in sustainable finance. Hence, additional work in sustainability metrics development that informs the investment sector of sustainable performance in companies would be of key importance. This article argues that there remain gaps in EU leadership for governing metrics development, and suggests that EU-level governance can be designed appropriately, especially in a multi-stakeholder manner, for metrics development and in relation to key information intermediaries in this space.
\end{abstract}

Keywords Sustainable finance $\cdot$ Sustainable taxonomy $\cdot$ Double materiality Sustainable benchmark $\cdot$ Sustainable index

\section{Introduction}

One of the means for achieving sustainable policy goals ${ }^{1}$ lies in mobilising the financial lever, i.e., to require financiers to make allocative decisions based on sustainable considerations, in order to steer economic activity towards sustainable outcomes. The financial lever is a meaningful one as private governance, often incentive-based, can steer behaviour in a manner that is also aligned with

\footnotetext{
${ }^{1}$ High-Level Expert Group on Sustainable Finance (HLEG) (2018).

Iris H-Y Chiu

hse-yu.chiu@ucl.ac.uk

1 Professor of Corporate Law and Financial Regulation, University College London, London, UK
} 
the achievement of collective goals. ${ }^{2}$ The financiers of corporate capitalism play a part in steering their debtor ${ }^{3}$ or investee companies ${ }^{4}$ towards behaviour that takes into account sustainability considerations.

The EU's sustainable finance reforms include the Sustainability Disclosure Regulation $2019^{5}$ and Taxonomy Regulation $2020,{ }^{6}$ as well as follow-on initiatives for the regulation of investment firms, funds and benchmarks. ${ }^{7}$ These reforms comprise (a) mandatory duties for regulated investment firms and fund managers to integrate sustainability risks; ${ }^{8}$ (b) mandatory sale and ongoing disclosure obligations for marketing sustainable products; ${ }^{9}$ and (c) defining sustainability objectives to prevent greenwashing. ${ }^{10}$ However, the financial lever relies keenly on market forces to affect market participants' actions. Key to the success of the financial lever is arguably the measurement of sustainability impact and achievement which would enable investment intermediaries and their investors to make relevant decisions on that basis.

EU regulations have achieved much in terms of specifying and standardising the sustainable objectives and outcomes for the financial lever. ${ }^{11}$ In particular, policy-makers embrace double materiality ${ }^{12}$ in measuring investment outcomes. This

\footnotetext{
2 Black (2003).

3 Discussed in relation to banks' roles in monitoring sustainability impact in debt financing, such as in project finance, by means of implementing the voluntary Equator Principles, see https://equator-princ iples.com/about/ (accessed 15 Nov 2021); and Herbertson and Hunter (2007); critically, Sarro (2012).

4 Socially responsible investors have been a driving force for influencing corporations in relation to socially responsible behaviour, either through portfolio selection processes or activism, see generally Gibson et al. (2018); Serafeim (2018); Kakeu (2017); Osthoff (2015). Investor trade bodies can also help promote best practices on the part of investors in responsible investment, see Yamahaki (2019). However, see critical discussions relating to passive investment and generally weak investment influence on corporate behaviour, Glac (2014), Grewal et al. (2016); Amba (2018).

5 Regulation (EU) 2019/2088 of the European Parliament and of the Council of 27 November 2019 on sustainability-related disclosures in the financial services sector (Sustainability Disclosure Regulation 2019).

${ }^{6}$ Regulation (EU) 2020/852 of the European Parliament and of the Council of 18 June 2020 on the establishment of a framework to facilitate sustainable investment, and amending Regulation (EU) 2019/2088 (Taxonomy Regulation 2020). Other relevant legislation such as amendments to corporate reporting, regulation of investment firms and funds, as well as benchmark regulation will be discussed in the article.

7 Communication from the Commission to the European Parliament, the Council, the European Economic and Social Committee and the Committee of the Regions: EU Taxonomy, Corporate Sustainability Reporting, Sustainability Preferences and Fiduciary Duties: Directing finance towards the European Green Deal (21 April 2021), https://eur-lex.europa.eu/legal-content/EN/TXT/?uri=CELEX:52021 DC0188 (accessed 15 Nov 2021).

8 Supra n. 5 and infra n. 21.

9 Regulations in nn. 5 and 6 supra.

10 Art. 2, Sustainability Disclosure Regulation 2019, as well as environmentally sustainable objectives defined in the Taxonomy Regulation 2020 and the forthcoming social taxonomy envisaged by the Commission, https://ec.europa.eu/info/sites/default/files/business_economy_euro/banking_and_finance/ documents/finance-events-210226-presentation-social-taxonomy_en.pdf (accessed 15 Nov 2021).

11 Supra nn. 5 and 6. See also Zetzsche and Sørensen (2021) in this volume.

12 See ESMA's emphasis on double materiality in 'ESMA supports IFRS Foundation's efforts on international standardisation in sustainability reporting', 16 Dec 2020), https://www.esma.europa.eu/pressnews/esma-news/esma-supports-ifrs-foundation $\% \mathrm{E} 2 \% 80 \% 99$ s-efforts-international-standardisation-in
} 
means that sustainable outcomes matter not only for their relevance to financial performance of investments. The universe of sustainability outcomes is large and varied, with many aspects susceptible to qualitative evaluation. There is unfinished work in relation to the development of sustainability metrics. Metrics refer not only to the outcomes or objectives but also to the selection and identification of suitable indicators which provide a rubric for measuring attainment. ${ }^{13}$ Further, the development of sustainability metrics must include choices about the tolerance level of the extent of attainment. Metrics development is important to facilitate the evaluations that need to be carried out by investment intermediaries in order to fulfil the newly introduced regulatory obligations. Further, metrics development goes beyond supporting the financial lever, as it provides for broader visibility and accountability for economic activity more generally, to stakeholders and society. Hence, in this article, we identify metrics governance as crucial to the EU's sustainable finance agenda and discuss how it may be further developed. Addressing such governance needs would likely be the next step in the evolution of the sustainable finance policy agenda. ${ }^{14}$ In doing so, we do not forget that there have already been bottom-up developments in the investment industry focused on 'ESG' (environmental, social and governance) indicators over the years, raising the question to what extent the EU's attempts at redefining sustainability cohere with or contest against those developments.

However, this article acknowledges the obvious, which is that the financial lever cannot be the 'whole answer' to achieving economic behavioural change towards sustainability. Financial mobilisation towards sustainability is ultimately incentivebased, and the corporate sector needs to translate into actions and conduct economic activity that is sustainable. Investment influence upon the corporate sector is only one piece of the mosaic for transforming corporate behaviour, ${ }^{15}$ and investors' behaviour is itself a subject of criticism and debate. ${ }^{16}$ Nevertheless, the development of regulatory steers for investor behaviour can play a valuable part in the policy mosaic towards mobilising sustainable corporate behaviour.

Section 2 provides an overview of the sustainable finance policy in the EU. Section 3 discusses the role of regulatory governance in redefining sustainability and what it has achieved. It discusses the needs for metrics development and what governance needs remain unmet. Section 4 argues that the EU is well placed to address the governance needs for sustainability metrics development and the next steps policy-makers should consider. Section 5 concludes.

\footnotetext{
Footnote 12 (continued) (accessed 15 Nov 2021).

13 Tanzil and Beloff (2006).

14 Maijoor (2020).

15 See MacNeil and Esser (2021) in this volume.

16 Gilson and Gordon (2013); Bebchuk and Hirst (2019); Fichtner and Heemskerk (2020).
} 


\section{The EU Sustainable Finance Agenda as Policy Lever}

As the investment sector wields significant influence, with global assets under management growing year on year, estimated to be at USD $\$ 145$ trillion by $2025,{ }^{17}$ policy-makers have started looking to the gatekeeping capacities of the investment sector. This is so that these intermediaries in capital markets can play a useful part in the governance landscape for shaping economic behaviour towards alignment with sustainable goals. ${ }^{18}$

The EU's sustainable finance strategy has brought about reforms in capital markets regulation. The Sustainability Disclosure Regulation 2019 now compels all financial market participants engaging in portfolio management or fund management (whether as mainstream pension or collective investment schemes, or as alternative investments funds ${ }^{19}$ to make mandatory disclosure of how they integrate sustainability risks in their investment decision-making. ${ }^{20}$ This also includes financial services providers that supply investment-based products as part of an insurance product. This mandatory disclosure obligation is to be upgraded shortly to a definitive duty to integrate sustainability risks into investment strategies, risk management and governance. ${ }^{21}$ Further, a range of new mandatory disclosure obligations apply to large investment firms and to the marketing and ongoing review of sustainably labelled investment products. ${ }^{22}$ In addition, and crucially, the redefinition of 'sustainability' has been legalised, proceeding from environmental sustainability ${ }^{23}$ to social development sustainability, in order to prevent 'greenwashing' in investment products, a problem identified by critics of self-regulating and self-labelled ESG products. $^{24}$

The EU's sustainable finance agenda has been built upon earlier policy nudging institutional investors towards becoming engaged shareholders in their investee companies. The EU Shareholders' Rights Directive 2017 introduced a regime of comply-or-explain for institutional investors ${ }^{25}$ in order to nudge ${ }^{26}$ them towards $^{2}$

\footnotetext{
17 PwC (2017).

18 https://sustainabledevelopment.un.org/?menu=1300 (accessed 15 Nov 2021).

19 Sustainability Disclosure Regulation 2019, Art. 2.

20 Ibid., Art. 3.

21 Commission Delegated Regulation to amend the Alternative Investment Fund Managers Directive, https://ec.europa.eu/finance/docs/level-2-measures/aifmd-delegated-act-2021-2615_en.pdf (dated 21 April 2021) (accessed 15 Nov 2021); Commission Delegated Directive to amend the UCITs Directive, https://ec.europa.eu/finance/docs/level-2-measures/ucits-directive-delegated-act-2021-2617_en.pdf (dated 21 April 2021) (accessed 15 Nov 2021); Commission Delegated Directive to amend the Markets in Financial Instruments Directive, https://ec.europa.eu/finance/docs/level-2-measures/mifid-2-delegatedact-2021-2612_en.pdf (dated 21 April 2021) (accessed 15 Nov 2021).

22 Sustainability Disclosure Regulation 2019, Arts. 4, 7, 8-11.

23 Arts. 9-17, Taxonomy Regulation 2020.

24 'Unregulated "greenwashing"? ESG investing is under the microscope as the money rolls in', CNBC News, 14 Oct 2020, https://www.cnbc.com/2020/10/14/esg-investing-meaning-is-under-the-microscopeas-the-money-rolls-in.html (accessed 15 Nov 2021).

25 Art. 3g.

26 Madsen (2021).
} 
more engaged behaviour, in the overall promotion of the long-term interests of beneficiaries. ${ }^{27}$ Such shareholder engagement can take place in relation to companies' corporate governance as well as their footprint in ESG matters. ${ }^{28}$ Earlier, to support investors' engagement role, the EU introduced regulation for listed companies to make relevant 'non-financial disclosures' in relation to environmental impacts, and impacts on employees, human rights, and anti-corruption matters. ${ }^{29}$

However, it can be argued that the shareholder engagement and corporate nonfinancial disclosure reforms suffer from a lack of connection to the public interest goals of sustainability. Shareholder engagement in response to corporate disclosure is very much in the nature of addressing the 'agency' problem, ultimately to steer companies towards being accountable to shareholders. These shareholders are also acknowledged to have their own private interests and mandates in relation to investment management. The nature of private corporate governance and the private nature of investment management duties may not sufficiently connect with the public interest goals of sustainability. ${ }^{30}$ This is because private incentives are bound up in the need to generate financial return, on the part of companies for their shareholders and on the part of institutional shareholders for their asset owners and beneficiaries. ${ }^{31}$ Although private incentives can be compatible with public interest goals, as empirical research has shown that investing in 'good' is largely compatible with investing 'well' in terms of financial performance, ${ }^{32}$ trade-offs between generating financial return and committing to sustainable behaviour have also been observed. ${ }^{33}$

In this manner, the EU's sustainable finance reforms take a step further by introducing regulatory steers in the objectives of investment management so that public interest goals in sustainability have to be internalised. However, the Sustainable Disclosure and Taxonomy Regulations introduced in 2019 and 2020 cannot over-prescribe or over-intrude into the freedom to design investment mandates and continue to co-opt market forces, but in a manner that nudges towards the promotion of: (a) conventional investment that internalises sustainability considerations, and (b) specially designed sustainable investments that deliver sustainable outcomes alongside financial ones. The latter market is growing in relation to investors' pro-social preferences, on the part of many institutions and individuals, ${ }^{34}$ and will be attractive for investment fund intermediaries.

\footnotetext{
27 Arts. 3h and 3i.

28 Arts. $3 \mathrm{~g}$ and $3 \mathrm{~h}$ in relation to non-financial performance. See also Principles 9-11, UK Stewardship Code, https://www.frc.org.uk/getattachment/5aae591d-d9d3-4cf4-814a-d14e156a1d87/StewardshipCode_Dec-19-Final-Corrected.pdf (accessed 15 Nov 2021).

29 Art. 19a, Non-financial Disclosure Directive 2014/95/EU.

30 Sjåfjell et al. (2017).

31 The fiduciary duty owed by funds to their beneficiaries is private in nature and centres on generating the necessary returns for the purpose of investment, although taking into account responsibility and sustainability issues is not per se irrelevant to the primary mandate, see UNEP FI (2019).

32 Friede et al. (2015); Durán-Santomil et al. (2019); but see sceptical evidence in La Torre et al. (2020).

33 Chen et al. (2017).

34 See infra nn. 42-44.
} 


\subsection{Baseline Duty of Integrating Sustainability Risks}

Under the Sustainability Disclosure Regulation, investment fund intermediaries are under a universal obligation to make mandatory disclosure of how they 'integrate sustainability risks'. 'Sustainability risk' is defined as an 'environmental, social or governance event or condition that, if it occurs, could cause an actual or a potential material negative impact on the value of the investment ${ }^{35}$ Such a definition adopts a 'single materiality' approach of treating sustainability risk as salient only if it materially affects investment performance. At a baseline, this is not novel and is consistent with the interpretation of fiduciary duty in private investment management. ${ }^{36} \mathrm{We}$ will return to this point shortly to discuss whether an opportunity has been missed to embed double materiality in the baseline regulation of investment management conduct.

Next, investment intermediaries of a certain scale, defined as having 500 employees or above, or being a parent company of such an undertaking, ${ }^{37}$ are mandated to account for principal adverse sustainability impacts (applying from 30 June 2021). This applies whether or not such financial services providers engage with sustainably labelled products. They must account for any adverse impact of their investment decision-making processes on sustainability objectives, for how adverse impacts are discovered and for the due diligence policies that are deployed.$^{38}$ Smaller providers may declare that they do not consider adverse sustainability impacts in their investment decision-making process but they must clearly explain why and whether this practice cuts across all their products. ${ }^{39}$ This means that smaller providers are subject to the broad duty to integrate sustainability risks as discussed above, but not specifically to the prescribed mandatory disclosure of due diligence policies and measurement of adverse sustainability impact imposed on larger investment intermediaries. In this manner, larger investment intermediaries are under an obligation that is more socially-facing in nature, i.e., to account for sustainability cost $a s$ such.

Although this approach seems proportionate in order to reduce compliance obligations for smaller fund intermediaries, the bifurcation adopted suggests that smaller firms can elect to be principally 'private-facing' and potentially 'exempt', subject to their explanation, from the scope of socially-facing accountability imposed on larger firms. There is a large sector of investment firms that are medium-sized and employ under 500 employees. Hence, it is questioned as to whether the EU's legalisation has achieved much in terms of steering investment management conduct towards double materiality.

It may be argued that the more remarkable reforms are those pertaining to mandatory disclosure and transparency. These, however, crucially rely on market discipline to be effective.

\footnotetext{
35 Art. 2(22), Sustainability Disclosure Regulation 2019.

36 See Freshfields Bruckhaus Deringer (2005); UNEP FI (2019); Richardson (2011).

37 Art. 4(3) and (4), Sustainability Disclosure Regulation 2019.

38 Art. 4(1)(a), ibid.

39 Art. 4(1)(b), ibid.
} 


\subsection{Mandatory Disclosure Obligations}

It may be argued that mandatory disclosure of sustainability risk integration by all investment intermediaries is already a step forward, as, left to a self-regulatory state, only 'socially responsible' investment funds would be under a contractual expectation to have regard to single materiality. Further, by 30 December 2022, financial services providers mandated to disclose principal adverse sustainability impacts must also make that transparency available at the level of each financial product. ${ }^{40}$ These disclosures are also regarded as pre-contractual in nature, therefore attracting market and legal discipline from investors. ${ }^{41}$

However, mandatory disclosure of material sustainability risks and principal adverse sustainability impacts will only change behaviour if asset owners and beneficiaries care about such information. There is increasing evidence that asset owners such as pension funds ${ }^{42}$ and pro-social individuals value the avoidance of adverse sustainable impact in their investment allocations. ${ }^{43}$ This is not necessarily the case with conventional institutions, ${ }^{44}$ and investment beneficiaries have highly heterogenous preferences. ${ }^{45}$ If market response is clear and effectively disciplines the investment management industry, such discipline can be much more effective than an extraction of compliance imposed by regulators. However, with the bifurcation in mandatory disclosure requirements applicable to larger and smaller investment intermediaries, investors arguably do not enjoy a level playing field for discipline effects to be transmitted. There would likely be mixed noise in relation to market discipline focused on material sustainability risks relating to investment performance and on adverse sustainability impact per se. In this manner, it may be preferable for policy-makers to consider whether to adopt double materiality as a universal standard. Smaller firms can be subject to less prescriptive governance, although they can be made to disclose how they manage double materiality, so that their priorities and processes can be subject to public scrutiny and accountability. ${ }^{46}$ This is arguably proportionate for smaller firms in view of compliance costs.

Mandatory disclosure obligations for marketing sustainably labelled products have been enhanced considerably. The Sustainability Disclosure Regulation clarifies that sustainably labelled finance goes beyond 'harm-based analysis', and should reflect the achievement of positive sustainability outcomes and not merely the avoidance of negative ones. Indeed 'sustainable investment' is defined in two dimensions: it should positively achieve specified sustainable outcomes and do 'no significant harm' to environmental and social objectives as a whole. ${ }^{47}$ The definition of 'sustainably labelled' relates to

\footnotetext{
${ }_{40}$ Art. 7, Regulation 2019/2088.

41 Art. 6, ibid.

42 Apostolakis et al. (2018); Delsen and Lehr (2019); de Haan et al. (2012).

43 Wins and Zwergel (2016); Ammann et al. (2018).

44 Jansson and Biel (2014); Ielasi and Rossolini (2019).

45 Apostolakis et al. (2016); also pro-social individual investors remain a minority, see Christiansen et al. (2019).

46 Parker (2000) in relation to the meta-regulatory technique.

47 Derived from Art. 2(17), Sustainability Disclosure Regulation 2019.
} 
an economic activity that contributes to an environmental objective, $[\ldots]$ as measured by key resource efficiency indicators on the use of energy, renewable energy, raw materials, water and land, on the production of waste, and greenhouse gas emissions, or on its impact on biodiversity and the circular economy, or an investment in an economic activity that contributes to a social objective, [...] [such as] tackling inequality or that fosters social cohesion, social integration and labour relations, or an investment in human capital or economically or socially disadvantaged communities, provided that such investments do not significantly harm any of those objectives and that the investee companies follow good governance practices, in particular with respect to sound management structures, employee relations, remuneration of staff and tax compliance.

Financial services providers who provide explicitly sustainably labelled products must explain how the environmental or social characteristics promoted by each product meet its characterisation, whether in active or in passive management. In an actively managed product, disclosure is to be made of the strategies designed to meet the relevant characteristics, including how the financial services provider defines the sustainability objective and how it measures its attainment or otherwise. ${ }^{48}$ The European Securities and Markets Authority (ESMA) will prescribe a template ${ }^{49}$ for such disclosure so that certain standards and comparability are attained.

In relation to passively managed products, financial services providers must disclose if the environmental or social characterisation is derived by benchmarking against indices for sustainable finance. ${ }^{50}$ It is not sufficient that financial services providers merely refer to a designated index to be satisfied of a product's environmental or social characteristics. They must disclose how the index is aligned or consistent with those characteristics and how alignment with it differs from a broad market index. ${ }^{51}$ Although financial services providers are in substance relying on an index provider's diligence and evaluation, there needs to be some level of intelligent engagement with indexers' methodologies ${ }^{52}$ in order to demonstrate why the index has been selected and to show the difference to sustainable performance made by adhering to the index. As there are huge inflows into passively managed ESG products, ${ }^{53}$ policy-makers have also set their sights on regulating index products adopted by investment funds in order to support the credibility of such products. ${ }^{54}$ We take the view that although index provider governance is an important aspect of

\footnotetext{
48 Arts. 8 and 10, ibid.

49 Draft technical standards as of 23 April 2020, https://www.esma.europa.eu/press-news/esma-news/ esas-consult-environmental-social-and-governance-disclosure-rules (accessed 15 Nov 2021).

50 Arts. 8 and 9, Sustainability Disclosure Regulation 2019.

51 Art. 9(1)(b), ibid.

52 Bianchi and Drew (2012) on the differences between indices.

53 'ESG index funds hit $\$ 250$ billion as pandemic accelerates impact investing boom', CNBC News, 2 Sep 2020, https://www.cnbc.com/2020/09/02/esg-index-funds-hit-250-billion-as-us-investor-role-inboom-grows.html (accessed 15 Nov 2021).

54 Benchmarks Regulation 2016/1011; amended by Regulation 2019/2089 (on EU Climate Transition Benchmarks, EU Paris-aligned Benchmarks and sustainability-related disclosures for benchmarks) dealing with 'low carbon' benchmarks for indexed funds.
} 
the sustainable finance regulatory agenda, a more holistic agenda for metrics governance is needed, a point we canvass in Section 4.

The Sustainability Disclosure Regulation provides a gold standard for the labelling of sustainable financial products. Although the Taxonomy Regulation does not outlaw 'lower' labels such as 'ESG' or 'socially responsible' products, ${ }^{55}$ the regulatory governance of the 'sustainable' label is intended to set standards as well as galvanise market choice. However, the effectiveness of such regulatory policy depends on the alignment between market choice and regulatory steering. If sustainably labelled products are more costly due to the more demanding compliance obligations, this could affect market choice and the demand side may be incentivised to settle for 'lower' labels.

In sum, the EU's sustainable finance reforms provide regulatory steers for the baseline integration of sustainability consciousness on the part of all investment intermediaries, as well as the market building of investment products that meet the purposes of double materiality, i.e., delivering on both investment and sustainable performance, hence avoiding greenwashing. We are of the view that although the EU has taken a step forward in legalising baseline investment management conduct in relation to sustainability risks, the conduct lever is relatively un-imposing on the majority of investment intermediaries not defined as 'large'. The obligation to integrate single materiality concerns merely consolidates bottom-up developments over the years, as many conventional investment firms are signatories to the UN Principles of Responsible Investment. It also remains to be seen how mandatory disclosure of principal adverse sustainability impact might change the behaviour of large investment intermediaries, who may then provide leadership for double materiality in conventional investment management. The more radical reform for now is the attempt to redefine sustainably labelled investment products and how this affects market interest and preferences.

In this respect, although EU policy-makers have achieved scientifically informed clarity in identifying the environmentally sustainable objectives in the Taxonomy Regulation and are developing a social taxonomy for social and governance objectives, these are objectives and outcomes which still require the support of measuring metrics in order to make sustainably labelled finance distinguishable and meaningful for the market. Although the Taxonomy Regulation provides environmentally sustainable outcomes, such as in relation to reduced emissions or the circular economy, it is questioned what level of granularity is defined for these outcomes ${ }^{56}$ and whether they are aggregates of even more granular proxy indicators. ${ }^{57}$ There may be a fine line between outcomes and proxy indicators, but outcomes often comprise a number of proxy indicators and how these are measured. Further, if double materiality is

\footnotetext{
$\overline{55}$ Art. 7, Taxonomy Regulation 2020.

56 ESAs, Joint Consultation Paper: Taxonomy-Related Disclosures (17 March 2021), https://www.esma. europa.eu/press-news/esma-news/esas-consult-taxonomy-related-product-disclosures (accessed 15 Nov 2021).

57 Karthik Ramanna, 'ESG accounting needs to cut through the greenwash', Financial Times, 17 Jan 2021, offers some insight into the type of 'accounting' or evaluative metrics that are needed for sustainability performance.
} 
embraced as an ethos, this must be reflected in the nature of measurement. Indeed in relation to social and governance goals many of which are qualitative in nature, the selection of a range of suitable and proximate indicators which afford a rubric for measurement, and the determination of the tolerance level for attainment need to be precisely made. This is besides the issue of debatability in the selection of social outcomes and goals in terms of inclusion/exclusion choices ${ }^{58}$ and how these reflect the social fabric in the EU as a whole, taking into account differences in social development and needs in different Member States.

The metrics for sustainable outcome evaluation remain an open field. However, this is a broader issue than for the purposes of investment intermediaries' product design, disclosures and conduct. The metrics for sustainable achievements or impact must fundamentally underpin economic activity generally, such as in corporate disclosures. ${ }^{59}$ Sustainable investments are largely made in private sector corporate entities, whether in the form of debt or equity securities, ${ }^{60}$ and corporate reporting forms an important cornerstone for investment intermediaries' evaluations, besides other sources of information such as those held by the World Bank, non-governmental organisations or media platforms. ${ }^{61}$ In this manner, investors need to have increased confidence in paying ${ }^{62}$ for the gold standard of 'sustainably labelled' investments, being sure that such investments are selected and evaluated on the basis of clear and suitable metrics. The governance of sustainability metrics can arguably go further in affecting investment choice architecture. ${ }^{63}$

This article argues that it is imperative that the EU develop follow-up governance in relation to sustainability metrics development. Metrics governance cuts across the spheres of corporate and financial institution reporting in order to enable market choice and discipline. As the sustainable finance reforms crucially rely on market

\footnotetext{
58 The social taxonomy reflects international consensus such as consistency with international governance standards on anti-bribery and tax avoidance, international human rights standards, and labour standards.

59 This is acknowledged to be in need of ongoing reform, see supra $\mathrm{n} .7$.

60 Sustainable investments defined for the purposes of financial institutions' reporting include investments in equity, debt off-balance sheet exposures and other fee-generating services such as trade finance, see EBA, Advice to the Commission on KPIs and methodology for disclosure by credit institutions and investment firms under the non-financial reporting standards on how and to what extent their activities qualify as environmentally sustainable according to the EU Taxonomy Regulation (Feb 2021), https:// www.eba.europa.eu/sites/default/documents/files/document_library/About\%20Us/Missions\%20and\% 20tasks/Call\%20for\%20Advice/2021/CfA\%20on\%20KPIs\%20and\%20methodology\%20for\%20disclosu res\%20under\%20Article\%208\%20of\%20the\%20Taxonomy\%20Regulation/963616/Report\%20-\%20Adv ice\%20to\%20COM_Disclosure\%20Article\%208\%20Taxonomy.pdf (accessed 15 Nov 2021). Further, the integration of sustainability risk into prudential risk measurement by financial institutions would affect their incentives to allocate credit or investment to activities that may adversely affect such measurement, see EBA, Draft implementing standards on prudential disclosures on ESG risks in accordance with Article 449a CRR (Consultation Paper, Feb 2021), https:/www.eba.europa.eu/sites/default/documents/files/ document_library/Publications/Consultations/2021/Consultation\%20on\%20draft $\% 20 I T S \% 20$ on $\% 20$ Pil lar\%20disclosures\%20on\%20ESG\%20risk/963621/Consultation\%20paper\%20on\%20draft $\% 20$ ITS $\%$ 20on\%20Pillar\%203\%20disclosures\%20on\%20ESG\%20risks.pdf (accessed 15 Nov 2021).

61 Lucy Fitzgeorge-Parker, 'ESG data - mind the gaps', Euromoney, 27 Aug 2020.

62 Corley (2019).

63 Amel-Zadeh and Serafeim (2018); Pilaj (2017).
} 
discipline for mandatory disclosures and on the market for sustainably labelled products, EU governance in metrics development seems unavoidable. In Section 3 we discuss the need for EU governance to be extended to the conceptual and implementational aspects of double materiality in order to secure clear, comparable and meaningful metrics development for users, so as to steer market choice in a manner aligned with public interest goals.

\section{Double Materiality}

Although EU policy-makers have signalled a preference for double materiality, the conceptual development of double materiality is only weakly evidenced and the implementation aspects of double materiality suffer from gaps. This Section critically explores where these areas require improvement in order to support governance for metrics development.

\subsection{Conceptual Gaps in Double Materiality}

First, in terms of what double materiality means, the Sustainability Disclosure Regulation provides examples of sustainable goals in its definition of 'sustainable investment', such as relating to efficient use of energy, enabling a circular economy, investing in human capital, and improving the position of socially disadvantaged communities. The Taxonomy Regulation provides more specific environmentally relevant goals in relation to climate change mitigation and adaptation, protection of water and marine resources, protecting biodiversity, and preventing pollution. These goals are valued per se rather than tied to their contribution to financial return.

The Taxonomy Regulation provides six environmentally sustainable goals and lists of indicators for each of the goals, but social goals are a work in progress. ${ }^{64}$ The sustainable goals developed in the EU's sustainable finance policy overlap to an extent but do not map fully onto the United Nations' Sustainable Development Goals, for example. ${ }^{65}$ Besides the issue of selection of goals and whether indicators for environmental and social goals are fully developed, ${ }^{66}$ it is also not taken for granted that the indicators developed for environmental goals provide clear metrics. ${ }^{67}$ Metrics are more granular in nature and provide a rubric for measuring attainment. Different metrics can also exist to show that an indicator of, for example, 'using sustainably sourced renewable materials' is met. We need metrics to measure

\footnotetext{
${ }^{64}$ See the EU's work on the social taxonomy, https://ec.europa.eu/info/sites/default/files/business_econo my_euro/banking_and_finance/documents/finance-events-210226-presentation-social-taxonomy_en.pdf (accessed 15 Nov 2021).

65 https://www.undp.org/content/undp/en/home/sustainable-development-goals.html\#: :text=The\% 20Sustainable\%20Development\%20Goals\%20(SDGs,peace\%20and\%20prosperity\%20by\%202030 (accessed 15 Nov 2021). It is also opined that indicators for SDG goals are themselves emerging, Bebbington and Unerman (2018).

${ }^{66}$ Gibson et al. (2018).

67 Cort and Esty (2020).
} 
what 'sustainably sourced' means, such as by reference to certifications, origins or processes, and what degree of renewability or recyclability materials should meet in order to be regarded as 'renewable'. Must materials be wholly recycled to meet the criteria or would 'partly renewable' suffice? In this regard, the development of metrics that are salient and reliable for showing the achievement of an indicator is still a work in progress. ${ }^{68}$ These metrics also have to be consistently applicable, within or across industries, ${ }^{69}$ be independently verifiable, ${ }^{70}$ and most of all, speak clearly to asset owners and beneficiaries in terms of choice framing. ${ }^{71}$ It is further queried whether sustainability metrics have been more developed with regard to adverse impact such as carbon emissions or toxic release emissions in relation to pollutants, compared to positive sustainability contributions. ${ }^{72}$ It may be more difficult to develop metrics for positive sustainability contributions as proxy indicators may be premature or selective, and it is uncertain what sort of timeframe is necessary to consider counterbalancing side effects. Finally, the Commission has also acknowledged that bottom-up feedback views the Taxonomy Regulation's categorisation of environmentally sustainable activities as being a somewhat narrow set, and a complimentary legislative initiative on a taxonomy for climate change mitigation activities is going to be developed. ${ }^{73}$

The governance for metrics development in the EU is faced with a number of challenges. To what extent would the EU engage with this comprehensively so as to provide a set of top-down metrics for standardisation purposes? Such work requires heavy lifting and may duplicate bottom-up developments in metrics, such as those relating to 'ESG'. There are already actors in this space that measure ESG performance, serving the universe of 'socially responsible' investment funds. ${ }^{74}$ Nevertheless, the existing industry of ESG metrics development is arguably premised on portfolio risk management and more aligned with single materiality, i.e., how ESG metrics affect investment performance. ${ }^{75}$ The key actors in this space include the Global Reporting Initiative ${ }^{76}$ Integrated Reporting Initiative, ${ }^{77}$ Sustainability Accounting Standards Board ${ }^{78}$ and more recently the International Financial Reporting Standards Foundation ${ }^{79}$ that are developing sustainability reporting metrics aimed at companies. The reporting standards issued by the Task Force on

\footnotetext{
68 Ibid.; Kotsantonis and Serafeim (2019).

69 Esty and Karpilow (2019); Leuz (2020).

70 Cort and Esty (2020).

71 Pilaj (2017).

72 Esty and Karpilow (2019).

73 See supra n. 7, p 3.

74 Based on techniques such as screening and exclusion, or stock-picking for 'best-in-class' performance, which means that ESG ratings are looked at in the relative and not absolute sense.

75 Richardson and Cragg (2010); Schäfer (2012).

76 https://www.globalreporting.org/ (accessed 15 Nov 2021).

77 https://integratedreporting.org/resource/international-ir-framework/ (accessed 15 Nov 2021).

78 https://www.sasb.org/ (accessed 15 Nov 2021).

79 IFRS (2020).
} 
Climate-related Financial Disclosures (TCFD) ${ }^{80}$ and now adopted in the Listing Rules for premium-listed companies on the London Stock Exchange ${ }^{81}$ are aimed at financial institution disclosures of transition and stranded asset risks, as well as corporate transparency. Further, there are many existing private sector specialists in ratings for environmental, social and governance performance, which support the industry of socially responsible investors, such as Viageo Eiris, ${ }^{82}$ Robeco Sam ${ }^{83}$ and Refinitiv. ${ }^{84}$ Index providers have also developed partnerships ${ }^{85}$ with ESG rating services or have built up in-house expertise ${ }^{86}$ to carry out evaluations in order to develop socially responsible or sustainable indices as benchmarks for passive investment managers.

However, it may be argued that private sector-developed 'ESG' metrics have been sub-optimally self-regulatory as they cater for single materiality ${ }^{87}$ Hence, would not such metrics cater for the baseline duty to integrate material sustainability risks for all investment intermediaries? In this manner, the bifurcation of compliance imposed on larger and smaller firms, especially in relation to the disclosure of 'principal adverse sustainability impact', draws attention to the distinctness of the obligation for larger firms which necessitates evaluative and reporting metrics. Further, as the EU distinguishes the sustainably labelled financial product from other ESG labels, there is a need for metrics to be developed for the double materiality of the superior labelled products. In this manner, it is arguable that top-down provision is needed not only of doubly material outcomes but to extend more granularly into metrics. That said, it is queried whether the market should be allowed to develop double materiality metrics in response to the new measures for the market building of sustainably labelled products. We have not yet proved market failure. An attempt by the EU to completely re-write the metrics for double materiality not only requires heavy lifting but is easily susceptible to user criticism. We perceive the need for but also hazards of a top-down approach to the establishment of alternative double materiality metrics which will only gain traction if private sector actors and international markets adopt them. Although top-down metrics provision is not ruled out, we argue that EU governance for metrics development should first provide groundwork in terms of ideological choices and underpinnings, and take into account private sector innovations and implementational tendencies.

At a broader and more conceptual level, metrics development embeds choices in relation to what matters for measurement. Commentators have opined that over time corporations have developed various measures for environmental or social impact

\footnotetext{
80 https://www.fsb-tcfd.org/ (accessed 15 Nov 2021).

81 Financial Conduct Authority (2020).

82 https://vigeo-eiris.com/ (accessed 15 Nov 2021).

83 https://www.robeco.com/uk/about-us/robecosam.html (accessed 15 Nov 2021).

$84 \mathrm{https}: / /$ www.refinitiv.com/en/financial-data/company-data/esg-data (accessed 15 Nov 2021).

85 Such as the Dow Jones Sustainability Index in partnership with Robeco SAM, as well as the MSCI KLD index which is the product of acquiring KLD as an ESG ratings service provider.

86 Such as the FTSE4Good / FTSE Russell Indices.

87 Diez-Cañamero et al. (2020).
} 
that are salient to them, usually in terms of economic cost, ${ }^{88}$ but also in relation to reputational salience and perceived stakeholder pressures. ${ }^{89}$ These are necessarily selective and corporate-centric, ${ }^{90}$ but provide a good starting point for metrics development to be standardised across an industry, or even industries. It needs to be ascertained to what extent metrics development by private sector bodies is wedded to such corporate-centric development of ESG measurement, and whether there should be public policy intervention ${ }^{91}$ that would compel other forms of measurement to be made to inform public interest of the sustainability footprint of corporate and economic activity. ${ }^{92}$ It has been observed that metrics development based on stakeholder perspectives can change metrics design considerably. ${ }^{93}$

Further, choices of perspective also need to be made in developing sustainability metrics. For example, environmental impact can be measured or expressed as deterioration in natural capital. But this form of measurement embeds an implicit assumption that natural capital can be appropriated as private property and monetised. ${ }^{94}$ Such a perspective need not be compatible with the sense of collective good in promoting sustainability objectives. It is arguable that metrics development implicates broader social and political choices in relation to sustainability goals and priorities. ${ }^{95}$ Hence, metrics development gives rise to fundamental questions in relation to the premises upon which they are built and what actors or influencers are part of the landscape for such development. In this manner, metrics development is not merely a matter for private governance. There is also a need for public-led scrutiny to be involved in shaping the premises upon which metrics are generated and the purposes metrics serve. ${ }^{96}$

Next, EU policy-makers should clarify the connection between sustainable outcomes as defined in the Sustainability Disclosure Regulation and the characteristics of good governance in investee companies. The definition of 'sustainable investment' in the Regulation comes across as providing that good governance is a necessary condition for the definition of sustainable investment. The characteristics of good governance relate to sound management structures, employee relations and tax compliance. There is actually less support in empirical research to show that good governance characteristics support the attainment of sustainable outcomes by companies, ${ }^{97}$ and no definitive causal correlations have been proposed, whether in terms

\footnotetext{
88 De Benedetto and Klemes (2015).

89 Alsayegh et al. (2020); Pitrakkos and Maroun (2020); Tadros and Magnan (2019).

90 Beske et al. (2020).

91 Such as mandatory conflict minerals disclosure under the EU Conflict Minerals Regulation 2017 in force from 2021 and the UK's Modern Slavery Act s54 on supply chain disclosure.

92 There is however the danger that compliance-based disclosure and measurement would be minimalist and undertaken only to manage legal risk, see Park (2019).

93 Diebecker et al. (2019).

94 Barter (2015); Martineau and Lafontaine (2020).

95 Nicholls (2020).

96 Questions raised in Gibassier (2015).

97 Dienes et al. (2016); Passador and Riganti (2019).
} 
of sustainable performance affecting good governance or otherwise. ${ }^{98}$ It is uncertain how this necessary condition works to frame sustainable investment choice. Could the conditions for good governance be treated as key or exclusive proxy indicators for sustainable investments? Has EU policy elevated the importance of governance factors so that other sustainability indicators may be outbalanced by these? Further, the metrics for good governance can be regarded as overly prescriptive, especially in relation to increasingly detailed corporate governance codes for listed companies. ${ }^{99}$ Yet, many corporate governance codes apply on a comply-or-explain basis in order to accommodate the private bargaining processes between companies and their shareholders. Does the inclusion of the necessity of governance characteristics in sustainable investment elevate the need for practically hard corporate compliance with corporate governance codes, if companies need to appeal to their sustainability-conscious institutional investors? There is also a significant discrepancy between the level of detail and prescription in corporate governance codes for listed companies (such as the UK one) and voluntary codes for companies that may be private but significant in economic footprint. ${ }^{100}$

Hence, there is more clarification that EU policy-makers can provide regarding the materiality of governance characteristics and their connection with double materiality. With the lack of European harmonisation in matters regarding corporate governance codes, reference to good governance, a matter subject to national and divergent governance, also seems incompatible with the harmonised EU-level governance intended to be provided over the concept of sustainable investment.

In addition, EU policy-makers should clarify the extent of compatibility between single materiality metrics that are being developed significantly by private sector bodies and double materiality metrics catering for the obligations of adverse impact disclosure by larger investment firms and for evaluating sustainably labelled investment products. Market demand has brought about the development of more established ESG metrics, which may be regarded as a narrower set and premised upon assumptions that do not necessarily embrace a holistic or comprehensive conceptualisation. ${ }^{101}$ ESG metrics meet the existing market demand for single materiality assessments, i.e., to measure for investors the sustainability performance of companies that matter for their financial performance. ${ }^{102}$ This is consistent with investors' familiar ground in portfolio risk management for making allocational decisions. ${ }^{103}$ Further, the use by credit rating agencies ${ }^{104}$ and financial analysts ${ }^{105}$ of financially material ESG ratings has also reinforced the trend towards developing metrics for single materiality.

\footnotetext{
98 Ibid.

99 Moore (2015).

100 Such as the Wates Principles, critically discussed in Barker and Chiu (2020).

101 Darton (2015); Fornasari (2020).

102 Aureli et al. (2019); Rogers and Serafeim (2019).

103 Hübel and Scholz (2020).

104 Cubas-Díaz et al. (2018); Del Giudice and Rigamonti (2020); Jon Hay, 'Fitch joins ESG caravan with relevance scores', Global Capital, 10 Jan 2019.

105 Hinze and Sump (2019); Kim et al. (2018).
} 
There is arguably a lack of incentive on the part of private sector actors in metrics development to deviate too much from single materiality, whether on the part of corporations themselves or on the part of service providers in supporting the investment industry. Embracing authentic double materiality requires new mindsets, resources and processes for measurement and evaluation, and would generate conflict situations with single materiality that may not be easy to reconcile. Taibi et al. ${ }^{106}$ report on a project aimed at partnering with a corporation to develop strong sustainability metrics that extend, and in some respects depart, from economic and financial materiality. Perhaps to no surprise, the project was ultimately not adopted by the corporate partner. This explains why earlier endeavours such as the Integrated Reporting Initiative $^{107}$ and True Value Capital Accounting ${ }^{108}$ have been adopted by some corporations based on single materiality. Of late, the Sustainability Accounting Standards, which focus on investor materiality, have become attractive to corporations and investors, ${ }^{109}$ and the merger of the SASB and IIRC further reinforce the development of single materiality metrics. ${ }^{110}$ The involvement of the IFRS in developing sustainability accounting standards that can be adopted globally, ${ }^{111}$ based on the IFRS' expertise in providing financial accounting standards, ${ }^{112}$ may also be geared towards single materiality drawing upon the IFRS' expertise. Further, it has been opined that although the GRI reporting standards that underlie many corporations' voluntary ESG reports are meant to appeal to a broad audience including shareholders and stakeholders, the nature of these standards has increasingly responded to investor materiality. ${ }^{113}$ There also seems to be substantial support in US commentary for mandatory disclosure of ESG factors by companies based on a single materiality standard, to be incorporated into SEC-mandated disclosure. ${ }^{114}$ In this manner, there may be significant international trends that support the introduction of a single materiality standard, as such a standard is more easily integrated within existing regulatory, legal and accounting frameworks. ${ }^{115}$ Indeed, the single materiality standard is likely to be developed on the basis of corporate reporting, such as the work undertaken in relation to the Impact-Weighted Accounts reporting standards for different sectors. ${ }^{116}$ In that manner, sustainability metrics that the investment community needs would not likely be developed in isolation from the movement

\footnotetext{
106 Taibi et al. (2020).

107 Discussed in Akisik and Gal (2020); Mervelskemper and Streit (2017).

108 See Hendriksen et al. (2016). Critique in Barter (2016), McElroy and Thomas (2015).

109 Grewal et al. (2017); Busco et al. (2020).

110 'IIRC and SASB intend to merge', 25 Nov 2020, https://www.iasplus.com/en/news/2020/11/iirc-andsasb-intend-to-merge (accessed 15 Nov 2021).

111 IFRS (2020).

112 Eroglu (2017); Klein (2017).

113 Fornasari (2020) and Busco et al. (2020) continue to see the GRI standards as being more holistic and inclusive in relation to ESG perspectives and materiality.

114 Fisch (2019); Harper Ho (2020); Saad and Strauss (2020).

115 Congruence with law is discussed in Jebe (2019). The support for mandatory disclosure of material ESG factors by corporations within existing securities regulation is discussed in Christiansen et al. (2019).

116 https://www.hbs.edu/impact-weighted-accounts/Pages/default.aspx (accessed 15 Nov 2021).
} 
towards metrics development for corporate sustainability accounting and reporting. European policy-makers need to forge a more holistic policy in relation to metrics development, a point which we explore in greater detail in the next Section.

It is arguable that single materiality metrics may be under-inclusive for double materiality purposes and in some respects contesting in nature. However, it cannot be definitively argued that single materiality measurements completely contradict or are irrelevant for the purposes of sustainable investment. There is also an inevitable extent of convergence between single and double materiality. As the initiatives of the IIRC and True Value Capital Accounting have shown, single materiality is not unconnected with double materiality, but it is the extent of under-inclusiveness or contradiction that is not well articulated. ${ }^{117}$ Would we leave it to investors with hybrid motivations, i.e., those interested in both financial and sustainable performance, to bring their demands to bear in order to shape metrics that would ultimately deliver hybrid signals, ${ }^{118}$ therefore exceeding mere single materiality? Or should policy-makers provide guidance and steering in light of the natural lack of incentives on the part of industry and markets to value double materiality? This is a fundamental policy dilemma for EU policy-makers as regulatory steering to recharacterise the obligations of investment firms in relation to being socially-facing, such as in relation to the mandatory disclosure of principal adverse impact by larger firms, introduces 'beyond-market' obligations and the necessity of a discipline different from market discipline. This may mean that there is a limited extent to which bottom-up market-based developments can cater for the EU's governance needs in relation to metrics. However, as the regulatory policy hybridises incentive-based discipline and socially-facing accountability, it would likely be impractical for EU policy-makers to presume that they should be the only ones to undertake a re-write of metrics for double materiality. Further, commentators have argued that what investors value as material is dynamic in nature ${ }^{119}$ and hybrid investors could play a part in shaping the development of more holistic metrics in due course.

In this complex landscape of public interest steers and private market incentives and developments, EU-level governance for metrics development should not be lacking, but should not be top-down either. ${ }^{120}$ We see a role for policy engagement with the scrutiny of premises underlying metrics development, critical consideration of the salience and comprehensiveness of metrics, ${ }^{121}$ and consideration of how balances between single and double materiality may be struck. Such governance roles encompass nuanced steering, oversight and market facilitation. In particular, the metrics development for adverse sustainability impact may be more mature than metrics development for measuring positive sustainable contribution. Metrics development

\footnotetext{
117 On the divergence between financial materiality and sustainable performance, see Perez (2016); Lipton (2020).

118 Some empirical research has mapped a positive correlation between investments in portfolios of ESG companies scored using the SASB standards and the attainment of UN SDG goals, see Antoncic et al. (2020); Betti et al. (2018).

119 Rogers and Serafeim (2019).

120 Maijoor (2020).

121 Pagano et al. (2018).
} 
for the latter runs the risk of being overly corporate-centric, such as looking at positive contribution from the lens of corporate opportunity. Metrics development for positive sustainability contribution is also fraught with issues relating to choice of success indicators and timeframes for evaluation. Policy-makers should harness the advantages of both convergence and competition amongst different private sectorbased metrics frameworks, ${ }^{122}$ and monitor the effectiveness of metrics frameworks for users. In this regard, policy-makers should also consider how third-party assurance providers ${ }^{123}$ can play a role and be appropriately governed in this landscape. Section 4 sets out the steps for EU-level governance in metrics development.

\subsection{Implementational Issues for Double Materiality}

Besides conceptual issues regarding the clarity of double materiality as a concept and how they shape policy choices in supporting metrics development, EU policymakers should extend oversight governance in relation to the implementational tendencies on the part of market participants. Market practice can deviate from policy intentions regarding how double materiality is used, even if such metrics are developed. ${ }^{124}$ Market practice can shape the prioritisation of sustainable goals based on the market's allocational functions.

First, even if the sustainable performance of investments is compelled to be evaluated on a double materiality basis, if the investment market prioritises certain materiality evaluations and gives them greater weight in allocational decisions, then the practice of prioritisation will give rise to marginalisation of the importance of certain double materiality metrics. This results in a feedback loop for corporate reporting which then reinforces investors' allocational decisions. It is observed that in the current landscape where metrics development is still emerging, conventional institutional investors are already undertaking endeavours to filter information relevant to their preferences from the noise of voluminous ESG information reported by corporations. ${ }^{125}$ Information users are behaviourally expected to choose and prioritise according to their interests and incentives. Some indications from empirical observations show that investors place emphasis on non-financial achievements such as gender diversity on boards or employee welfare, and have even demanded that these be built into chief executives' remuneration packages. ${ }^{126}$ In this manner, policy-makers' mandating of double materiality in investment evaluations and disclosures would not prevent more granular market choices from being made in relation to the perceived salience of certain metrics over others. This could play a significant part in shaping selected corporate changes in behaviour ${ }^{127}$ and allocative decisions

\footnotetext{
122 Maijoor (2020).

123 Del Giudice and Rigamonti (2020).

124 Perez (2016).

125 Betti et al. (2018); Mervelskemper and Streit (2017); Aureli et al. (2019). Lueg et al. (2019) look at risk salience of ESG reporting, for example.

126 'Half of FTSE 100 companies link executive pay to ESG targets', Financial Times, 17 March 2021.

127 Le Roux and Pretorius (2019).
} 
by the investment sector. Forces of isomorphism amongst conventional investment funds may thus converge on a narrower market-based selection of metrics development and prioritisation, and hence influence what is relatively more important in terms of environmental or social sustainability goals.

Industry practice in terms of prioritisation of certain sustainability metrics over others may influence the development of fund products, whether actively or passively managed, in favour of certain popular sustainability goals and metrics. Examples are the corporation's expense ratio for human capital training, the emission levels of greenhouse gases or pollutants, and the level of social or media attention on particular popular indicators. ${ }^{128}$ In this manner, sustainable investment can develop in a selective manner prioritising support for certain sustainable objectives over others. Hence, the policy preference for double materiality may still not connect private investment holistically and comprehensively with the public interest goals of sustainability.

However, it can be argued that EU policy-makers should not expect the private investment sector to provide comprehensively for environmentally and socially sustainable development goals. The UN SDGs, for example, are envisaged to be achieved by a mixture of public and development finance ${ }^{129}$ as well as private finance. ${ }^{130}$ Hence, policy-makers should be prepared to observe and monitor market-led developments in terms of sustainable finance in order to discern the gaps in sustainability objectives that are not met by private sector finance. There is scope for policy-makers to consider the public goods nature of gaps and the need for public and development finance, or blended finance involving public-private partnership ${ }^{131}$ to meet that need. The enrolment of private sector-led sustainable finance could be perceived as useful for policy-makers' determination of an optimal division of labour between market-driven provision and public provision. Policy-makers should not merely rely on private sector financial provision to meet sustainability goals in total.

However, contrary to the above argument, investors with particular preferences and investment funds with particular mandates, such as impact investment funds, could incentivise the development of specific metrics demonstrating specific impact to be delivered. ${ }^{132}$ In niche quarters, new forms of double materiality may voluntarily arise and be developed. The needs of different investment quarters may exert different demands in terms of development of double materiality metrics.

Policy-makers and regulators should be attentive to market developments and be prepared to engage in a governance role in relation to the bottom-up development and implementation of sustainability metrics.

\footnotetext{
128 Such as a convergence of investor interest upon human rights violations information, Bradford (2020).

129 Georgeson and Maslin (2018).

130 Walker et al. (2019).

131 OECD (2018); see for critical discussion Tan (2019).

132 Reeder et al. (2015). The difficulties of measuring impact and integrating this into financial materiality are canvassed in Brandstetter and Lehner (2015).
} 
Finally, many conventional institutional investors make allocations to sustainable investments that are passively managed. Although the Sustainability Disclosure Regulation expects fund intermediaries to justify their choice of the benchmark index and to demonstrate sustainable performance, chiefly by comparing the sustainable benchmark index to a conventional broad-based index, the modus of performance demonstration in this manner results in the need to merely prove 'relative' but not absolute sustainable performance. Fund intermediaries only need to show that sustainably labelled funds improve on conventionally benchmarked funds' sustainable performance as a whole. ${ }^{133}$ Relative improvement does not mean that sustainable goals have been achieved in significant measure. Further, sustainable indices often aggregate a range of sustainable metrics and scores, and smooth over detail in relation to different granular aspects of sustainable performance. ${ }^{134}$ It is uncertain if the EU regime for benchmarks regulation fully addresses the information-signalling effects of sustainable indices, a point we return to in Section 4.

In sum, we see EU-level governance for metrics development as being essential in terms of underpinning ideological clarification and choices, as well as coordinating multi-stakeholder governance in public-private development. Some co-existence and co-development with single materiality metrics development is likely inevitable and to an extent can be productive. EU-level governance should also extend into implementational monitoring and considering how best to meet the gaps left by the market in terms of meeting certain sustainability objectives. Ultimately, the governance for metrics development should extend beyond the financial lever, and Section 4 offers some thoughts on next steps in securing a more holistic agenda for such governance.

\section{EU Governance in Sustainability Metrics Development}

We argue that EU-level governance should be extended to overseeing the development of sustainability metrics for consistent use in relation to the governance of economic activity generally, and not just pursuant to investment fund regulation. Such harmonisation is consistent with the policy agenda in the European Green Deal which seeks to situate economic growth pursuits within a sustainability framework. ${ }^{135}$ The Green Deal focuses on environmentally sustainable goals, while social development policies are still emerging in the EU's '2030' agenda that endorses the UN Sustainable Development Goals. ${ }^{136}$ In this context of wider policy agendas, sustainability metrics for investors should not be developed in isolation from

\footnotetext{
133 Antoncic et al. (2020).

134 Brakman Reiser and Tucker (2020) find that passive ESG funds pay lip service to substantive ESG performance, while 'aggregating' sustainability measurement can result in the obscuring of granular negative information, see Fiaschi et al. (2020).

135 https://ec.europa.eu/info/strategy/priorities-2019-2024/european-green-deal_en (accessed 15 Nov 2021).

136 https://ec.europa.eu/environment/sustainable-development/SDGs/index_en.htm (accessed 15 Nov 2021).
} 
corporate $^{137}$ and financial regulation more generally, as these affect economic activities that relate to the achievement of the Green Deal or the 2030 agenda. Such a broader agenda is important in order to contextualise the financial lever as only one part of the policy mosaic. The financial lever's efficacy is likely incomplete if other complimentary policy levers that seek to change corporate behaviour are not developed.

\subsection{Holistic Agenda for Governance of Metrics Development}

First, there is a case for reforming the corporate disclosure regime for non-financial sustainability impact and performance, so as to shed light on the sustainability evaluation of economic activity. The reforms should target scope as well as metrics governance, incorporating the needs of the financial lever discussed above. In relation to scope, mandating ${ }^{138}$ corporate reporting of sustainability performance across the corporate sector should extend beyond application to listed companies, which are currently the entities subject to mandatory non-financial reporting under the Non-financial Disclosure Directive 2014. There should not be a narrow focus to make sustainability matter only if fund-raising is in issue. The contribution of adverse or positive sustainable impact from all economic activities is relevant for the assessment of sustainability objectives achievement. ${ }^{139}$ A more universal case is warranted for corporate transparency of the sustainability performance of private as well as publicly traded corporations. This is of relevance to investors in relation to new forms of capital formation, such as in equity crowdfunding for small and medium-sized enterprises, as well as for a broader range of stakeholders concerned about the impact of economic activity. After all, SMEs contribute to at least $50 \%$ of the EU economy and employ over 100 million people. ${ }^{140}$

The UK Government ${ }^{141}$ is planning to introduce mandatory disclosure of climate impact risk and risk management by listed companies, companies traded on the Alternative Investment Market, large private companies and Limited Liability Partnerships with 500 employees and above. This measure recognises a wider scope of business and economic activity with potential climate impact. Although it may be argued this is proportionate for smaller companies in view of the regulatory burden, sustainability may be a collective good that should be shared by all,

\footnotetext{
137 MacNeil and Esser (2021) and Sheehy (2021) in this volume.

138 Also referring to fragmented and weak practices in voluntary reporting so far, Esty and Karpilow (2019); Sarfaty (2013).

139 Lipton (2020).

140 https://ec.europa.eu/growth/smes_en\#: :text=Small\%20and\%20medium\%2Dsized\%20enterprises\% 20(SMEs)\%20are\%20the \%20backbone,every\%20sector\%20of\%20the\%20economy (accessed 15 Nov 2021).

141 UK BEIS, 'Consultation on requiring mandatory climate-related financial disclosures by publicly quoted companies, large private companies and Limited Liability Partnerships (LLPs)', March 2021, https://assets.publishing.service.gov.uk/government/uploads/system/uploads/attachment_data/file/ 972422/Consultation_on_BEIS_mandatory_climate-related_disclosure_requirements.pdf (accessed 15 Nov 2021).
} 
even the smallest businesses. The European Commission also now acknowledges that improved mandatory disclosure is needed for corporate reporting beyond the qualitative and principles-based approach in the 2014 Directive. It now proposes the contours of a Corporate Sustainability Reporting Directive envisaged to standardise sustainability disclosures for the entire corporate sector, including small and medium-sized enterprises but subject to proportionate application. ${ }^{142}$

It remains uncertain to what extent the recognition of the need to extend the scope of mandatory sustainability disclosures to the corporate sector includes policy endeavours for the governance of metrics development. In order to support consistent, comparable and meaningful corporate disclosure, the metrics against which sustainability impacts and achievements are reported should ideally be acceptable as proximate and measurable indicators for particular outcomes, and capable of being standardised. Mandating items for disclosure, such as those susceptible to qualitative disclosure, has often attracted criticism in relation to the lack of yardsticks for judging such disclosure. For example, in the UK, both private and publicly traded companies are subject to reporting obligations under the Modern Slavery Act ${ }^{143}$ in order to provide transparency on corporate due diligence into supply chains and to prevent modern slavery and human trafficking. The Act did not extend into metrics governance and adopted a principles-based approach on the overall qualitative nature of the reporting. The principles-based approach under the Act is being reviewed ${ }^{144}$ for greater prescription and consistency as flexibility and open-endedness have only resulted in vague development of indicators. Weak and fragmented reporting is also the experience in the US in relation to reporting on sourcing and due diligence policies for conflict minerals in the Democratic Republic of Congo, ${ }^{145}$ without the specific development of clear metrics. These examples highlight a need for governance of metrics development, as the agenda for double materiality is to be a holistic one.

It is arguable that the Taxonomy Regulation has made a first attempt at metrics governance for non-financial corporate reporting. The Taxonomy Regulation includes an amendment to the EU Non-financial Disclosure Directive to compel listed companies to make disclosure of certain expenditure levels connected with sustainable activities. ${ }^{146}$ These disclosures are intended to reflect real levels of commitment by companies to sustainable activities, 'if they put their money where their mouths are'. Corporations are to disclose three key financial indicators: ${ }^{147}$ the proportion of turnover in products or services in economic activities that can be associated with environmentally sustainable activities as defined in the Taxonomy Regulation; the proportion of capital expenditure related to assets or processes associated

\footnotetext{
142 Supra n. 7.

143 Section 54 of the Modern Slavery Act 2015.

144 UK Home Department (2019), pp 40-41, government consultation on reforms as of 22 Sep 2020, see https://assets.publishing.service.gov.uk/government/uploads/system/uploads/attachment_data/file/ 919937/Government_response_to_transparency_in_supply_chains_consultation_21_09_20.pdf (accessed 15 Nov 2021).

145 Sankara et al. (2019).

146 Art. 8.

147 ESMA, Final Report: Advice on Article 8 of the Taxonomy Regulation, Feb 2021.
} 
with economic activities that can be classified as environmentally sustainable; and the proportion of operating expenses related to assets or processes associated with economic activities that are environmentally sustainable.

Capital expenditure relates to expenditure on planned projects or activities that are intended to yield sustainable outcomes in a 5-year timeframe or such other timeframe that may be justified. Operating expenditures are direct costs only and are usually shorter-term in nature and not to be duplicated with capital expenditure. These corporate disclosures, focusing on the level of financial commitment by corporations to sustainable outcomes, provide information at a 'harder' level than the qualitative reporting envisaged under the Non-financial Disclosure Directive. Although financial commitments do not perfectly translate into sustainable outcomes and performance, they can be treated as proxy metrics, and allow investors to probe further upon engagement, and also to make inferences and comparisons. There is however a hazard: such numerical disclosures can obscure qualitative disclosures or become unduly relied upon as shorthand information. Further, such disclosures seem too remote in relation to sustainability outcomes, and also do not reflect issue or outcome specificity.

Although the Commission's proposed Corporate Sustainability Reporting Directive looks promising in terms of scope, the approach is to leave to delegated legislation to develop sustainability indicators for corporate reporting. There is uncertainty as to whether this heralds an entirely public model of metrics prescription. Metrics development benefits from the expertise of epistemic communities of actors, hence private sector participation in metrics development would be valuable. A co-governance $^{148}$ framework could be optimal in ensuring that metrics development is subject to sufficient and inclusive debates and monitoring, so that single and double materiality needs can be addressed and reflected in metrics development. In this manner, a multi-stakeholder framework for metrics development, governed by regulatory oversight, could be the way forward, a point we elaborate below.

Further, we also consider that a blend of capital markets policy and company law may be relevant for fund-raising by small and medium-sized enterprises. For example, harmonised EU regulation ${ }^{149}$ has been introduced for equity crowdfunding, entailing obligations for standardised key information disclosure ${ }^{150}$ by issuers on crowdfunding platforms which are usually SMEs and unlisted private companies. The regulatory regime is proportionate and does not extend the gamut of mandatory securities disclosure to SME issuers on equity crowdfunding platforms. We suggest that further harmonised regulation can provide for the inclusion of sustainability performance in issuer disclosure, especially if relevant to their business models. Such a disclosure requirement could be enabling in nature, supporting the promotion of funding opportunities and channels for private companies. There is a risk that funding for private companies or SMEs to engage in sustainability initiatives

\footnotetext{
148 Ackermann (2004); also see Finck (2018) in relation to governance of emerging blockchain technologies.

149 Regulation (EU) 2020/1503 on crowdfunding service providers.

150 Ibid., Arts. 23-24.
} 
can become marginalised if institutional investors' allocations to sustainable finance are concentrated upon listed companies, since only listed companies are subject to the existing reporting obligations in the Non-financial Disclosure Directive and are included in stock exchange indices.

\subsection{Relationship with Metrics Development by the Private Sector}

It is yet unclear whether the Commission's proposed Corporate Sustainability Reporting Directive envisages a comprehensive policy-led 're-write' of sustainability metrics reflecting double materiality. There are hazards with such an approach to metrics governance. The top-down provision of sustainability metrics can more clearly reflect the public interest in double materiality, a phenomenon that can be insufficiently internalised in market-based developments. However, it can also be disengaged with market-based needs and result in prescriptions that compel private sector participants to reconcile competing needs for single materiality evaluations and double materiality compliance. Hence, this article prefers a governance approach for metrics development that is co-governance in nature where private sector development is not treated as irrelevant or separate from the regulatory regime. Complementarities and co-educational opportunities should be developed between public sector, private sector and stakeholder governance in a multi-stakeholder space.

This article proposes that the European Securities and Markets Authority (ESMA) can lead a multi-stakeholder framework or committee, besides its stakeholder panel that feeds into general policy and rule-making, to be dedicated to the monitoring of sustainability metrics development for the holistic agenda of regulating corporate disclosure and financial product evaluation.

ESMA can take leadership in engaging with key developers of metrics, such as the SASB/IIRC merged entity, IFRS and GRI, so that the multi-stakeholder committee may be consulted upon or have observer status at key policy meetings. Further, such a multi-stakeholder committee should comprise sufficient representation from non-commercially based stakeholders who are better able to give opinions on double materiality as distinguished from financial or economic materiality. ${ }^{151}$ These may include experts such as drawn from the Stockholm Resilience Centre that have introduced the concept of planetary boundaries ${ }^{152}$ for sustainable economic conduct, scientific experts on environmental and social developments, non-governmental organisations, and charitable groups with interests in social development. Inclusive and diverse governance groups are often better able to bring balanced perspectives and rich debates to issue areas, as a form of 'tripartite' governance model involving the pillars of public policy, industry and civil society. ${ }^{153}$ Such input governance may evolve into more or less intense forms of formal or informal governance, but as a start, policy-makers and civil society should be engaged in the conceptual and

\footnotetext{
151 Diebecker et al. (2019).

152 https://www.stockholmresilience.org/ (accessed 15 Nov 2021).

153 Omarova (2012).
} 
implementational development of sustainability metrics, as many significant implications flow from such development. Metrics development should not be totally left to market-based forces.

In this manner, EU policy-makers can also consider developing a legislative framework for the endorsement of certain private-sector developed metrics, similar to the model adopted for the international accounting standards developed by the IFRS, ${ }^{154}$ though not necessarily centring upon the IFRS per se. This would go beyond the issuance of non-binding guidelines such as has already been undertaken by the European Commission. ${ }^{155}$ The adoption of the IFRS' international accounting standards was pursuant to the policy of enabling cross-border capital mobility in the Single Market ${ }^{156}$ and also fostered a significant trend of international convergence upon the IFRS based on trading relations with the EU. ${ }^{157}$ Of course, the IFRS had been sufficiently well-established at the point of the EU's adoption, and it can be argued that in a landscape of emerging sustainability metrics development, the EU should not prematurely endorse any particular standards or bodies in order to distort competition. However, there is already indication of soft endorsement of the TCFD's climate disclosure standards, which is based on single materiality. ${ }^{158}$ This may be due to the international underpinnings of the TCFD led by the Financial Stability Board. Hence, the EU can benefit from a more formal and systematic framework for endorsement of sustainability metrics that should also benefit from multi-stakeholder input as discussed earlier.

Any endorsement framework should be inclusively informed and also be accountable for decision-making. In this manner, the governance framework at EU level can monitor the status of competition amongst sustainability metrics providers and pull levers in order to foster competition or innovation, as well as to offer convergence where that is timely. If, for example, certain metrics gain wide practical acceptance, then an endorsement that fosters convergence can be useful for industry and stakeholders. The endorsement mechanism further opens up channels for the EU governance framework to engage with leading providers of endorsed standards, in order to provide a form of continuing co-governance.

The endorsement framework and process are themselves a form of governance that can be exercised over sustainability metrics development and attracts private sector leaders to engage with policy-makers and ESMA in the EU. Although such a governance role for the EU in relation to endorsing IFRS standards has not been uncontroversial, ${ }^{159}$ the bringing to bear of discourse and debate is crucial for the

\footnotetext{
154 Directive 2013/34/EU.

155 Infra n. 158.

156 Armstrong et al. (2012).

157 Ramanna and Sletten (2013).

158 European Commission's non-binding guidelines for reporting under the Non-financial Disclosure Directive, see European Commission, Guidelines on reporting climate-related information (2019), https://ec.europa.eu/finance/docs/policy/190618-climate-related-information-reporting-guidelines_en.pdf (accessed 15 Nov 2021).

159 Bischof and Daske (2016) on the tortuous journey for endorsing IFRS 9; also see Eroglu (2015, 2017); Hijink (2013).
} 
shaping of sustainability metrics, which, as Section 3 has discussed, has conceptual implications beyond the financial sector.

\subsection{Governing Information Intermediaries in Sustainable Metrics Development}

Finally, this article suggests that EU-level governance for metrics development should be extended to information intermediaries of sustainability metrics generally. 'Informediaries' for sustainability or ESG information are often relied upon as they provide shorthand information for easy adoption ${ }^{160}$ by active managers in socially responsible portfolios or by passive managers benchmarked to an index. Indeed, we predict elsewhere ${ }^{161}$ that the EU sustainable finance agenda is likely to mobilise the passive investing sector more significantly, and providers of sustainability indices therefore wield great market influence.

It may be argued that index providers for passively managed investment funds are already regulated under the Benchmarks Regulation, ${ }^{162}$ hence there is existing EUlevel governance over these entities. Further, the EU introduced the 'Low Carbon Benchmarks' Regulation $2019^{163}$ to set minimum standards for benchmarks that are labelled as 'climate transition' or 'Paris-aligned'. This is a good starting point for index providers who wish to use these labels for their benchmarks. Further developments in the social taxonomy and other benchmarks may be provided for in regulatory reform.

However, it is queried whether the Benchmarks Regulation addresses the issues specific to sustainability indices. The governance for the derivation of benchmarks is one issue, but this does not encompass all the issues in relation to metrics development as such. Granular metrics development is still relevant to active management and impact investing strategies, as well as to closer investor and stakeholder scrutiny into both corporate and investment allocation behaviour.

The Benchmarks Regulation was developed in the wake of the scandals relating to the manipulation of financial benchmarks for pricing variable interest rate contracts, i.e., the LIBOR and EURIBOR manipulation scandals. ${ }^{164}$ Hence, the regulatory approach is to subject administrators of benchmarks to proper governance in relation to their conflicts of interest management, internal control, accountability functions, oversight of data collection and input into the derivation of benchmarks, as well as their oversight of submitters of such data. ${ }^{165}$ Administrators are also to

\footnotetext{
160 Vives and Wadhwa (2012).

161 Chiu (2021).

162 Regulation 2016/1011 on benchmark regulation.

163 Regulation (EU) 2019/2089 on EU Climate Transition Benchmarks, EU Paris-aligned Benchmarks and sustainability-related disclosures for benchmarks.

164 'Libor scandal: the bankers who fixed the world's most important number', The Guardian, 18 Jan 2017, https://www.theguardian.com/business/2017/jan/18/libor-scandal-the-bankers-who-fixed-theworlds-most-important-number (accessed 15 Nov 2021); 'Two former traders handed jail terms in Euribor manipulation case', Financial Times, 19 July 2018, https://www.ft.com/content/c970a0c0-8b53-11e8b18d-0181731a0340 (accessed 15 Nov 2021).

165 Regulation 2016/2011, Arts. 4-11, 15, 16.
} 
develop robust, reliable and resilient methodologies for deriving benchmarks and to make these methodologies transparent. ${ }^{166}$ Further, significant and critical benchmarks are subject to more intrusive regulatory supervision and requirements to maintain their integrity and continuity. ${ }^{167}$ These provisions have been clearly aimed at the self-regulatory and opaque nature of bank panel submissions of hypothetical lending prices in order to derive the inter-bank offered rate benchmarks. However, the Regulation has broadened the definition of benchmarks to encompass indices adopted by investment funds to measure their performance, as indices function in a similar manner for financial evaluation and had been self-regulatory prior to the Regulation.

Although the broadly framed aspects of administrator governance in the Benchmarks Regulation can apply to index providers, the regulation of methodology may arguably be broad and under-inclusive. Different from the issues dogging price benchmarks, which is that there may be only hypothetical and small selections of data based on submitters' input, the issue with regard to sustainability indices is that index providers often have a wealth of information to manage, and there is opacity and variation in how they assess such information and aggregate it in order to derive the shorthand of the benchmark. ${ }^{168}$

The processes of aggregation by index providers of various sustainability data are underpinned by assumptions of salience and weight given to indicators. ${ }^{169}$ The shorthand result does not usually offer transparency as to the prioritisation of objectives and metrics. ${ }^{170}$ For example, empirical research has found little difference between socially-responsible labelled portfolios and conventional ones, where investments in oil and gas companies are routinely made in the former. ${ }^{171}$ Further, empirical research has also found companies included in the Dow Jones Sustainability Index that have been fraught with scandals for regulatory non-compliance or that are polluters. ${ }^{172}$ Rating and index differences can be ascribed to business model differences amongst informediaries, such as 'who pays for the ratings', ${ }^{173}$ and ideological and methodological underpinnings ${ }^{174}$ that differ amongst providers.

It is likely that specific governance requirements for methodologies of aggregation by sustainability index providers may be needed in terms of explaining their priorities, use of underlying metrics and trade-offs. This is not yet observed in the recent reforms introduced to the Benchmarks Regulation to clarify the meaning of 'low carbon' benchmarks. The reforms oblige index providers to be aligned with certain goals such as the EU's climate transition emission targets. This is outcome-focused and, arguably, index providers could curate the index based on

\footnotetext{
166 Arts. 12 and 13, ibid.

167 Arts. 20-25, ibid.

168 Chiu (2010/2011).

169 E.g., the Canberra aggregation method, see Brandi et al. (2014).

170 Jitmaneeroj (2016); Esty and Cort (2017); Fiaschi et al. (2020).

171 Nitsche and Schröder (2018).

172 Arribas et al. (2019).

173 Eccles et al. (2015).

174 Chelli and Gendron (2013); Eccles and Stroehle (2019).
} 
clear disclosures by companies that meet the targets. However, would companies included in such a low carbon index be regarded as generally 'sustainable'? How would the single issue of emission achievement sit with other sustainability indicators and metrics for the index construction? Index providers are likely more attracted to multi-issue sustainability, and the credibility of aggregation methodologies and their transparency remain in need of governance. Further, it is unlikely that a prescriptive approach to all possible index labels can practically be undertaken at the EU level, as this approach cannot prevent market innovations and developments for index labels that are not covered by the prescriptive approach.

We posit that the governance of informediaries for sustainability metrics development should be more encompassing and substantive. These include not only index providers but also ratings providers and analysts more broadly, as well as assurance providers for corporate sustainability reporting. Ratings providers and analysts are not all absorbed by index providers and there are independent entities in this space. ${ }^{175}$ A regulatory focus only on benchmarks regulation would obscure the need for a more holistic and consistent framework for governing the roles of other actors in metrics development. Further, both input and output legitimacy for informediaries' and assurance work can be improved by engaging with multi-stakeholder governance including policy and civil society actors.

There are arguably three models for governing important financial sector informediaries, from which insights can be drawn for developing the governance of sustainability metrics developers and informediaries. One model is in the credit ratings regulatory regime, which is not dissimilar from the benchmarks regulatory regime, the other is in the disclosure regulation for proxy advisers implemented largely in soft law. For assurance providers, the model governing financial auditors can be consulted.

Credit rating agencies have been subject to pan-European regulation ${ }^{176}$ after the global financial crisis of 2007-9, as they contributed to providing flawed creditworthiness assessments of structured financial products, which ultimately led to market and institutional stress in global financial systems. ${ }^{177}$ Regulatory governance is extended to structural factors in credit rating business models that may affect objectivity ${ }^{178}$ and the robustness and rigour of credit rating methodologies. ${ }^{179}$ This is arguably similar to the regulation of benchmark administrators. Hence, the basic rubric of entity regulation can be considered for all sustainability metrics developers, but more refined consideration should be given to issues specific to the development of sustainability metrics. These issues are: the ideological underpinnings of metrics, how single and double materiality may be reconciled, and the need for

\footnotetext{
175 Such as Bloomberg ESG or Viageo Eiris.

176 Regulation (EC) No 1060/2009 on credit rating agencies.

177 McVea (2010).

178 As regards regulating conflicts of interest management, see also Bai (2010).

179 Regulation 1060/2009, Art. 8; see also Commission Delegated Regulation (EU) 447/2012, Arts. 4-7.

See critical discussion in Chiu (2013).
} 
multi-stakeholder input. Further, supervisory governance is useful for backtesting rating methodologies and the effectiveness of metrics.

It may, however, be regarded as excessive that regulation is extended to sustainability metrics developers as significant problems have yet to surface. Nevertheless, the extension of regulatory governance for metrics developers in sustainability can foster a more level and credible playing field, and can be regarded as enabling in nature.

In the alternative, a more proportionate model for governing the role of another information intermediary can be found in the disclosure regulation for proxy advisers and ESMA's informal governance of them. Leading proxy advisers have significant market share ${ }^{180}$ and there have been concerns that they would play a systemic role in shareholder voting and corporate governance trends. ${ }^{181}$ Proxy advisers formed a collective group called the Best Principles Group to put forward a set of recommendations guiding their disclosures of research and house voting policies, their conflicts of interest management policies and how they communicate with their clients and relevant stakeholders. ${ }^{182}$ ESMA conducted a review of proxy advisers' adherence to their best principles and did not find cause for more severe regulatory intervention, therefore indicating that disclosure-based regulation coupled with soft law in best practices can be sufficient for market discipline. ${ }^{183}$ The EU Shareholder Rights Directive 2017 ultimately settled for this model of proportionate governance where proxy advisers should disclose if they adhere to a set of best practices in making their recommendations. ${ }^{184}$ There is also empirical evidence that systemic reliance on proxy advisers is not found, ${ }^{185}$ and therefore their influence is not so potent as to warrant direct regulatory intervention.

It may be warranted for sustainability metrics developers to be subject to a form of disclosure regulation that is proportionate and minimalist at first, like under the Shareholder Rights Directive 2017 for proxy advisers. Transparency can be required in relation to key issues that should be subject to policy-makers' and multi-stakeholders' scrutiny, such as research and methodological policies for sustainability data and data processing, the adoption and robustness of certain metrics, the conflicts of interest management policies that may affect ratings and index inclusion decisions, the use of automated technologies in data processing and policies employed against bias and for periodic review. Governance actors should monitor to what extent such disclosures affect metrics development, market adoption and reliance, so as to discern the effects of market discipline. A more proportionate approach to regulatory governance is an acceptable starting point.

\footnotetext{
180 Choi et al. (2010).

181 Ibid.

182 Best Practice Principles for Providers of Shareholder Voting Research and Analysis (2014), https:// bppgrp.info/wp-content/uploads/2014/03/BPP-ShareholderVoting-Research-2014.pdf (accessed 15 Nov 2021).

183 ESMA, Report: Follow-up on the Development of the Best Practice Principles for Providers of Shareholder Voting Research and Analysis (2015).

184 Art. 3j.

185 'Big investors ignore proxy advisers on controversial votes', Financial Times, 8 Feb 2020.
} 
Regarding assurance providers, bottom-up developments indicate that there is a convergence upon assurance provision for corporate reporting using the GRI or AA1000 standards for non-financial voluntary reporting. ${ }^{186}$ Indeed, the organisation AccountAbility, which has developed the AA1000 reporting standards, has issued its own assurance standard, the AA1000AS. ${ }^{187}$ The International Federation of Accountants has also issued the ISAE3000 assurance standard for the accounting profession undertaking non-financial reporting assurance. ${ }^{188}$ However, bottomup developments currently support assurance for single materiality reporting, and there may be a need to develop assurance capabilities for double materiality metrics and reporting. This is an area where policy steering, multi-stakeholder governance and private sector development can engage with one another. Empirical research has generally found assurance for non-financial reporting to be useful, ${ }^{189}$ e.g., motivating corporate restatements, ${ }^{190}$ hence both policy support for the development of an assurance industry that can cater for double materiality and governance oversight of such an industry may be useful.

Drawing from regulatory oversight of the auditing industry, the governance development for this industry has moved from professional self-regulation to regulatory oversight, in the wake of corporate scandals the signs of which could not be usefully detected from earlier transparency. ${ }^{191}$ Conflicts of interest management, ${ }^{192}$ professional standards in auditing ${ }^{193}$ and the lack of competition in the auditing industry ${ }^{194}$ have been major concerns for a long time. Assurance providers in the audit industry would likely benefit from being covered by auditor regulation, as similar issues such as conflicts of interest management and industry oligopoly are present. However, it may be viewed as disproportionate to regulate ahead of market failures, and there is scope to explore a disclosure-based regime such as for proxy advisers who are bound by soft law for best practices in governance and conflicts of interest management to begin with. This can also apply to non-audit entities providing assurance for non-financial reporting. However, the more pressing issue for non-financial assurance is in relation to what professional standards of assurance are needed for newly emerging sustainability metrics. Emerging standards of assurance may also need to be forged with multi-stakeholder input in the face of the need to assure double materiality, as such assurance is unlike financial reporting assurance targeted at capital markets. There is a socially-facing dimension of assuring for public and stakeholder

\footnotetext{
186 E.g., the Sustainability Report Assurance, https://www.sgs.com/en/sustainability/sustainability-repor ting/sustainability-report-assurance-sra (accessed 15 Nov 2021), is based on GRI or AA1000 reporting.

187 https://www.accountability.org/standards/aa1000-assurance-standard/ (accessed 15 Nov 2021).

188 https://www.iaasb.org/publications/international-standard-assurance-engagements-isae-3000-revisedassurance-engagements-other-audits-or-0 (accessed 15 Nov 2021).

189 Sam and Tiong (2015); Chen et al. (2019).

190 Chen et al. (2019).

191 Such as the Enron scandal, discussed in Coffee (2002); more recently the UK's Carillion and Patisserie Valerie scandals, see House of Commons (2018).

192 Ibid.

193 Brydon (2019).

194 Competition and Markets Authority (2018).
} 
consumption, and the development of assurance standards should incorporate this dimension.

In sum, we see the extension of EU-level governance in sustainability metrics development as necessary and inevitable, although we caution against a completely top-down approach of re-writing metrics over existing private sector-based developments. Such governance should be holistic in terms of fostering credible metrics development for economic activity generally and should involve co-governance with private sector and stakeholder entities. Policy-makers may consider a spectrum of soft to legalised regimes for sustainability informediaries and metrics developers.

\section{Conclusion}

This article argues that the regulatory steers in the recent EU Sustainable Disclosure and Taxonomy Regulations rely heavily on the outworking of market-based governance to meet public interest goals in sustainable finance. Hence, additional work in sustainability metrics development that informs the investment sector of sustainable performance in companies would be of key importance. This article argues that there remain gaps in EU leadership for governing metrics development, and suggests that EU-level governance can be designed appropriately, especially in a multistakeholder manner, for metrics development and in relation to key information intermediaries in this space.

Acknowledgements I am grateful for the support of the Centre for Banking and Financial Law for facilitating the Sustainable Finance Conference between UCL and NUS on 16 April 2021. Comments from Iain MacNeil, Eva Micheler, David Rouch and Dirk Zetzsche are gratefully acknowledged. All errors and omissions are mine.

Open Access This article is licensed under a Creative Commons Attribution 4.0 International License, which permits use, sharing, adaptation, distribution and reproduction in any medium or format, as long as you give appropriate credit to the original author(s) and the source, provide a link to the Creative Commons licence, and indicate if changes were made. The images or other third party material in this article are included in the article's Creative Commons licence, unless indicated otherwise in a credit line to the material. If material is not included in the article's Creative Commons licence and your intended use is not permitted by statutory regulation or exceeds the permitted use, you will need to obtain permission directly from the copyright holder. To view a copy of this licence, visit http://creativecommons.org/licen ses/by/4.0/.

\section{References}

Ackermann J (2004) Co-governance for accountability: beyond 'exit' and 'voice.' World Dev 32:447-463 Akisik O, Gal G (2020) Integrated reports, external assurance and financial performance: an empirical analysis on North American firms. Sustain Account Manag Policy J 11:317-350

Alsayegh MF, Rahman AR, Homayoun S (2020) Corporate economic, environmental, and social sustainability performance transformation through ESG disclosure. Sustainability 12:1-20

Amba S (2018) Corporate sustainability: do executives and investors care? An empirical study. Int J Manag Mark Res 11:19-26

Amel-Zadeh A, Serafeim G (2018) Why and how investors use ESG information: evidence from a global survey. Finance Anal J 74:87-103 
Ammann M, Bauer C, Fischer S, Müller P (2018) The impact of the Morningstar Sustainability Rating on mutual fund flows. https://ssrn.com/abstract=3068724. Accessed 15 Nov 2021

Antoncic M, Bekaert G, Rothenberg R, Noguer M (2020) Sustainable investment - exploring the linkage between Alpha, ESG, and SDG's. https://ssrn.com/abstract=3623459. Accessed 15 Nov 2021

Apostolakis G, Kraanen F, van Dijk G (2016) Pension beneficiaries' and fund managers' perceptions of responsible investment: a focus group study. Corp Gov 16:1-20

Apostolakis G, Van Dijk G, Blomme RJ, Kraanen F, Papadopoulos AP (2018) Predicting pension beneficiaries' behaviour when offered a socially responsible and impact investment portfolio. J Sustain Finance Invest 8:213-241

Armstrong CS, Barth ME, Jagolindzer AD, Riedl EJ (2012) Market reaction to the adoption of IFRS in Europe. http://ssrn.com/abstract=1265032. Accessed 15 Nov 2021

Arribas I, Espinós-Vañó MD, García F, Morales-Bañuelos PB (2019) The inclusion of socially irresponsible companies in sustainable stock indices. Sustainability 11:2047

Aureli S, Gigli S, Medei R, Supino E (2019) The value relevance of environmental, social, and governance disclosure: evidence from Dow Jones Sustainability World Index listed companies. Corp Soc Responsib Environ Manag 27:43-52

Bai L (2010) On regulating conflicts of interests in the credit rating industry. NYU J Legis Public Policy 13:253-312

Barker RM, Chiu IH-Y (2020) Examining the Wates Principles for large private companies as a social contract for business-society relations. Int Comp Corp Law J 14, chapter 3

Barter N (2015) Natural capital: dollars and cents/dollars and sense. Sustain Account Manag Policy J 6:366-373

Barter N (2016) A review of 'A New Vision of Value' - old wine, new bottle'. Sustain Account Manag Policy J 7:531-538

Bebbington J, Unerman J (2018) Achieving the United Nations Sustainable Development Goals. Account Audit Account J 31:2-24

Bebchuk L, Hirst S (2019) Index funds and the future of corporate governance: theory, policy and evidence. Columbia Law Rev 119:2029-2146

Beske F, Haustein E, Lorson PC (2020) Materiality analysis in sustainability and integrated reports. Sustain Account Manag Policy J 11:162-186

Betti G, Consolandi C, Eccles RG (2018) The relationship between investor materiality and the Sustainable Development Goals: a methodological framework. Sustainability 10:2248

Bianchi RJ, Drew ME (2012) Sustainable stock indices and long-term portfolio decisions. J Sustain Finance Invest 2:303-317

Bischof J, Daske H (2016) Interpreting the European Union's IFRS endorsement criteria: the case of IFRS 9. http://ssrn.com/abstract=2803567. Accessed 15 Nov 2021

Black J (2003) Enrolling actors in regulatory systems: examples from UK financial services regulation. Public Law 63-91

Bradford H (2020) Demand has more seeing inclusion of ESG metrics. Pensions and Investments 48:3. https://www.pionline.com/investing/demand-has-more-seeing-inclusion-esg-metrics. Accessed 15 Nov 2021

Brakman Reiser D, Tucker A (2020) Buyer beware: variation and opacity in ESG and ESG index funds. Cardozo L Rev 41:1921-2018

Brandi HS, Daroda RJ, Olinto AC (2014) The use of the Canberra metrics to aggregate metrics to sustainability. Clean Technol Environ Policy 16:911-920

Brandstetter L, Lehner OM (2015) Opening the market for impact investments: the need for adapted portfolio tools. Enterprise Res J 5:87-107

Brydon, Sir Donald (2019) The quality and effectiveness of audit: independent review. https://www.gov. uk/government/publications/the-quality-and-effectiveness-of-audit-independent-review. Accessed 15 Nov 2021

Busco C, Consolandi C, Eccles RG, Sofra E (2020) A preliminary analysis of SASB reporting: disclosure topics, financial relevance, and the financial intensity of ESG materiality. https://ssrn.com/abstr act $=3548849$. Accessed 15 Nov 2021

Chelli M, Gendron Y (2013) Ratings and the disciplinary power of the ideology of numbers. J Bus Ethics 112:187-203

Chen P-C, Ballou B, Grenier JH, Heitger DL (2019) Sustainability assurance's link to reporting quality. J Account. https://www.journalofaccountancy.com/news/2019/oct/sustainability-assurance-link-toreporting-quality-201919354.html. Accessed 15 Nov 2021 
Chen RCY, Hung S-W, Lee C-H (2017) Does corporate value affect the relationship between corporate social responsibility and stock returns? J Sustain Finance Invest 7:188-196

Chiu IH-Y (2010/2011) Standardization in corporate social responsibility reporting and a universalist concept of CSR? A path paved with good intentions. Florida J Int Law 22:361-400

Chiu IH-Y (2013) Regulatory governance of credit rating agencies in the EU: the perils of pursuing the holy grail of rating accuracy. Eur J Risk Regul 4:209-226

Chiu IH-Y (2021) Building a single market for sustainable finance in the EU - mixed implications and the missing link of digitalisation. European Company and Financial Law Review, forthcoming

Choi SJ, Fisch JE, Kahan M (2010) The power of proxy advisors: myth or reality? Emory Law J 59:869-918

Christensen HB, Hail L, Leuz C (2019) Adoption of CSR and sustainability reporting standards: economic analysis and review. ECGI Working Paper No. 623/2019. http://ssrn.com/abstract_id=34277 48. Accessed 15 Nov 2021

Christiansen C, Jansson T, Kallestrup-Lamb M, Noren V (2019) Who are the socially responsible mutual fund investors? http://ssrn.com/abstract=3128432. Accessed 15 Nov 2021

Coffee JC Jr (2002) Gatekeepers. OUP, Oxford

Competition and Markets Authority (2018) Statutory Audit Market Study. https://www.gov.uk/cma-cases/ statutory-audit-market-study. Accessed 15 Nov 2021

Corley E (2019) Sustainable investment: the golden moment. In: London Institute of Banking and Finance (ed) Banking on change: the development and future of financial services. John Wiley \& Sons, Chichester, ch 6

Cort T, Esty D (2020) ESG standards: looming challenges and pathways forward. Organ Environ 33:491-510

Cubas-Díaz M, Sedano MÁM (2018) Do credit ratings take into account the sustainability performance of companies? Sustainability 10:4272

Darton RC (2015) Setting a policy for sustainability: the importance of measurement. In: Klemes J (ed) Assessing and measuring environmental impact and sustainability. Elsevier, ch 14

De Benedetto L, Klemes J (2015) The Environmental Performance Strategy Map: an integrated life cycle assessment approach to support the strategic decision-making process. In: Klemes J (ed) Assessing and measuring environmental impact and sustainability. Elsevier, ch 11

de Haan M, Dam L, Scholtens B (2012) The drivers of the relationship between corporate environmental performance and stock market returns. J Sustain Finance Invest 2:338-375

Del Giudice A, Rigamonti S (2020) Does audit improve the quality of ESG scores? Evidence from corporate misconduct. Sustainability 12:5670

Delsen L, Lehr A (2019) Value matters or values matter? An analysis of heterogeneity in preferences for sustainable investments. J Sustain Finance Invest 9:240-261

Diebecker J, Rose C, Sommer F (2019) Spoiled for choice: does the selection of sustainability datasets matter? https://ssrn.com/abstract=3359508. Accessed 15 Nov 2021

Dienes D, Sassen R, Fischer J (2016) What are the drivers of sustainability reporting? A systematic review. Sustain Account Manag Policy J 7:154

Diez-Cañamero B, Bishara T, Otegi-Olaso JR, Minguez R, Fernández JM (2020) Measurement of corporate social responsibility: a review of corporate sustainability indexes, rankings and ratings. Sustainability $12: 2153$

Durán-Santomil P, Otero-González L, Correia-Domingues RH, Reboredo JC (2019) Does sustainability score impact mutual fund performance? Sustain J 11:2972

Eccles RG, Stroehle JC (2019) Exploring social origins in the construction of ESG measures. http://ssrn. com/abstract $=3212685$. Accessed 15 Nov 2021

Eccles RG, Herron J, Serafeim G (2015) Reliable sustainability ratings. In: Hebb T, Hawley JP, Hoepner AGF, Neher AL, Wood D (eds) The Routledge handbook of responsible investment. Routledge, Oxford, ch 48

Eroglu ZGK (2015) Whose Trojan horse? Dynamics of resistance against IFRS. Univ Pa Int Law J 36:89-190

Eroglu ZGK (2017) The political economy of international standard setting in financial reporting: how the United States led the adoption of IFRS across the world. Northwest J Int Law Bus 37:457-512

Esty DC, Cort T (2017) The data challenges that remain. In: Kronsinsky C, Purdom S (eds) Sustainable investing: revolutions in theory and practice. Routledge Earthscan, ch 9

Esty DC, Karpilow Q (2019) Harnessing investor interest in sustainability: the next frontier in environmental information regulation. Yale J Reg 36:625-692 
Fiaschi D, Giuliani E, Nieri F, Salvati N (2020) How bad is your company? Measuring corporate wrongdoing beyond the magic of ESG metrics. Bus Horiz 63:287-299

Fichtner J, Heemskerk EM (2020) The new permanent universal owners: index funds, patient capital, and the distinction between feeble and forceful stewardship. Econ Soc 49:493-515

Financial Conduct Authority (2020) Proposals to enhance climate-related disclosures by listed issuers and clarification of existing disclosure obligations, 21 Dec 2020. https://www.fca.org.uk/publicatio ns/policy-statements/ps20-17-proposals-enhance-climate-related-disclosures-listed-issuers-andclarification-existing. Accessed 15 Nov 2021

Finck M (2018) Blockchain regulation and governance in Europe. CUP, Cambridge

Fisch JE (2019) Making sustainability disclosure sustainable. Geo LJ 107:923-966

Fornasari F (2020) Knowledge and power in measuring the sustainable corporation: stock exchanges as regulators of ESG factors disclosure. Wash U Global Stud L Rev 19:167-233

Freshfields Bruckhaus Deringer (2005) A legal framework for the integration of environmental, social and governance issues into institutional investment. Report for the UNEP Finance Initiative. https://www.unepfi.org/fileadmin/documents/freshfields_legal_resp_20051123.pdf. Accessed 15 Nov 2021

Friede G, Busch T, Bassen A (2015) ESG and financial performance: aggregated evidence from more than 2000 empirical studies. J Sustain Financ Invest 5:210-233

Georgeson L, Maslin M (2018) Putting the United Nations sustainable development goals into practice: a review of implementation, monitoring, and finance. Geograph Environ. https://doi.org/10.1002/ geo2.49.Accessed15Nov2021

Gibassier D (2015) The corporate reporting landscape: a market for virtue or the virtue of marketization? Sustain Account Manag Policy J 6:527-536

Gibson R, Krüger P, Mitali SF (2018) The sustainability footprint of institutional investors. ECGI Working Paper No. 571/2018. https://ssrn.com/abstract=2918926. Accessed 15 Nov 2021

Gilson RJ, Gordon JN (2013) The agency costs of agency capitalism activist investors and the revaluation of governance rights. Columbia Law Rev 113:863-928

Glac K (2014) The influence of shareholders on corporate social responsibility. Econ Manag Financ Mark 9:34-72

Grewal J, Hauptmann C, Serafeim G (2017) Material sustainability information and stock price informativeness. https://ssrn.com/abstract=2966144. Accessed 15 Nov 2021

Grewal J, Serafeim G, Yoon A (2016) Shareholder activism on sustainability issues. Harvard Business School Working Paper No. 17-003. https://www.hbs.edu/faculty/Pages/item.aspx?num=51379. Accessed 15 Nov 2021

Gutsche G, Ziegler A (2019) Which private investors are willing to pay for sustainable investments? Empirical evidence from stated choice experiments. J Bank Finance 102:193-214

Haar B (2012) Civil liability of credit rating agencies - regulatory all-or-nothing approaches between immunity and over-deterrence. http://ssrn.com/abstract=2198293. Accessed 15 Nov 2021

Harper Ho V (2020) Disclosure overload? Lessons for risk disclosure \& ESG reform from the Regulation S-K Concept Release. Vill L Rev 65:67-91

Hendriksen B, Weimer J, McKenzie M (2016) Approaches to quantify value from business to society: case studies of KPMG's True Value methodology. Sustain Account Manag Policy J 7:474-493

Herbertson K, Hunter D (2007) Emerging standards for sustainable finance of the energy sector. Sustain Dev. L. \& Pol'y 7:4-9

High-Level Expert Group on Sustainable Finance (HLEG) (2018) Financing a sustainable European economy. https://ec.europa.eu/info/sites/info/files/180131-sustainable-finance-final-report_en.pdf. Accessed 15 Nov 2021

Hijink S (2013) Towards European accounting law? http://ssrn.com/abstract=2233089. Accessed 15 Nov 2021

Hinze A-K, Sump F (2019) Corporate social responsibility and financial analysts: a review of the literature. Sustain Account Manag Policy J 10:183-207

House of Commons (2018) Carillion plc. https://publications.parliament.uk/pa/cm201719/cmselect/ cmworpen/769/76902.htm. Accessed 15 Nov 2021

Hübel B, Scholz H (2020) Integrating sustainability risks in asset management: the role of ESG exposures and ESG ratings. J Asset Manag 21:52-69

Ielasi F, Rossolini M (2019) Responsible or thematic? The true nature of sustainability-themed mutual funds. Sustain J 11:3304 
IFRS (2020) Consultation paper on sustainability reporting. https://www.ifrs.org/content/dam/ifrs/proje ct/sustainability-reporting/consultation-paper-on-sustainability-reporting.pdf. Accessed 15 Nov 2021

Jansson M, Biel A (2014) Investment institutions' beliefs about and attitudes toward socially responsible investment (SRI): a comparison between SRI and non-SRI management. Sustain Dev 22:33-41

Jebe R (2019) The convergence of financial and ESG materiality: taking sustainability mainstream. Am Bus Law J 56:645-702

Jitmaneeroj B (2016) Reform priorities for corporate sustainability: environmental, social, governance, or economic performance? Manag Decis 54:1497-1521

Kakeu J (2017) Environmentally conscious investors and portfolio choice decisions. J Sustain Finance Invest 7:360-378

Kim S, Maas K, Perego P (2018) The effect of publication, format and content of integrated reports on analysts' earnings forecasts. In: Boubaker S (ed) Research handbook of finance and sustainability. Edward Elgar, Cheltenham, ch 28

Klein I (2017) A change in accounting, a change in law. Del J Corp 1 CHK 42:51-76

Kotsantonis S, Serafeim G (2019) Four things no one will tell you about ESG data. J Appl Corp Financ 31:50-58

La Torre M, Mango F, Cafaro A, Leo S (2020) Does the ESG index affect stock return? Evidence from the Eurostoxx50. Sustainability 12:6387

Le Roux C, Pretorius M (2019) Exploring the nexus between integrated reporting and sustainability embeddedness. Sustain Account Manag Policy J 10:822-843

Leuz C (2020) Keynote speech, ECGI Webinar on Sustainable Finance, 4 Dec 2020

Lipton AM (2020) Not everything is about investors: the case for mandatory stakeholder disclosure. Yale J on Reg 37:499-572

Lueg K, Krastev B, Lueg R (2019) Bidirectional effects between organizational sustainability disclosure and risk. J Clean Prod 229:268-277

MacNeil IG, Esser I-m (2021) From a financial to an entity model of ESG. European Business Organization Law Review, this volume

Madsen MB (2021) Behavioural economics in European corporate governance-much ado about nudging? Eur Bus Law Rev 32:295-316

Maijoor S (2020) The three (apparent) paradoxes of sustainability reporting and how to address them. Keynote speech, 8 December 2020. https://www.esma.europa.eu/sites/default/files/library/esma32-67765_speech_steven_maijoor_-_the_three_paradoxes_of_sustainability_reporting_and_how_to_addre ss_them.pdf. Accessed 15 Nov 2021

Martineau R, Lafontaine J-P (2020) When carbon accounting systems make us forget nature: from commodification to reification. Sustain Account Manag Policy J 11:487-504

McElroy MW, Thomas MP (2015) The MultiCapital Scorecard. Sustain Account Manag Policy J 6:425-438

McVea H (2010) Credit rating agencies, the subprime mortgage debacle and global governance: the EU strikes back. ICLQ 59:701-730

Mervelskemper L, Streit D (2017) Enhancing market valuation of ESG performance: is integrated reporting keeping its promise? Bus Strateg Environ 26:536-549

Moore MT (2015) 'Whispering sweet nothings': the limitations of informal conformance in UK corporate governance. J Corp Law Stud 15:95-138

Nicholls JA (2020) Integrating financial, social and environmental accounting. Sustain Account Manag Policy J 11:745-769

Nitsche C, Schröder M (2018) Are SRI funds conventional funds in disguise or do they live up to their name? In: Boubaker S, Cumming D, Khuong Nguyen D (eds) Research handbook of investing in the triple bottom line. Edward Elgar, Cheltenham, ch 19

OECD (2018) Making blended finance work for the Sustainable Development Goals. https://www.oecd.org/ dac/making-blended-finance-work-for-the-sustainable-development-goals-9789264288768-en.htm. Accessed 15 Nov 2021

Omarova S (2012) Bankers, bureaucrats, and guardians: toward tripartism in financial services regulation. J Corp Law 37:621-674

Pagano MS, Sinclair, Yang T (2018) Understanding ESG ratings and ESG indexes. In: Boubaker S (ed) Research handbook of finance and sustainability. Edward Elgar, Cheltenham, ch 18

Park SK (2019) Social responsibility regulation and its challenges to corporate compliance. Brook J Corp Fin Com L 14:39-52

Parker C (2000) The open corporation. CUP, Cambridge 
Passador ML, Riganti F (2019) Less is more in the age of information overload: the paradigm shift from a shareholder- to a stakeholder-oriented market. NYU JL Bus 15:567-651

Osthoff Peer (2015) What matters to SRI investors? In: Hebb T, Hawley JP, Hoepner AGF, Neher AL, Wood $\mathrm{D}$ (eds) The Routledge handbook of responsible investment. Routledge, Oxford, ch 54

Perez O (2016) The green economy paradox: a critical inquiry into sustainability indexes. Minn JL Sci Tech 17:153-219

Pilaj H (2017) The choice architecture of sustainable and responsible investment: nudging investors toward ethical decision-making. J Bus Ethics 140:743-753

Pitrakkos P, Maroun W (2020) Evaluating the quality of carbon disclosures. Sustain Account Manag Policy J 11:553-589

PwC (2017) Asset \& wealth management revolution: embracing exponential change. https://www.pwc.com/ ng/en/press-room/global-assets-under-management-set-to-rise.html. Accessed 15 Nov 2021

Ramanna K, Sletten E (2013) Network effects in countries' adoption of IFRS. Harvard Business School Working Paper No. 10-092. http://ssrn.com/abstract=1590245. Accessed 15 Nov 2021

Reeder N, Colantonio A, Loder J, Rocyn Jones G (2015) Measuring impact in impact investing: an analysis of the predominant strength that is also its greatest weakness. J Sustain Finance Invest 5:136-154

Richardson B (2011) From fiduciary duties to fiduciary relationships for socially responsible investing: responding to the will of beneficiaries. J Sustain Finance Invest 1:5-19

Richardson B, Cragg W (2010) Being virtuous and prosperous: SRI's conflicting goals. J Bus Ethics 92:21-39

Rogers J, Serafeim G (2019) Pathways to materiality: how sustainability issues become financially material to corporations and their investors. Harvard Business School Working Paper No. 20-056. https://ssrn. com/abstract $=3482546$. Accessed 15 Nov 2021

Saad AI, Strauss D (2020) A new 'reasonable investor' and changing frontiers of materiality: increasing investor reliance on ESG disclosures and implications for securities litigation. Berkeley Bus LJ 17:391-433

Sam CY, Tiong PNC (2015) An investigation of the corporate responsibility report assurance statements of the Big Four banks in Australia. Journal of Economics Library 2:3-14

Sankara J, Patten DM, Lindberg DL (2019) Mandated social disclosure: evidence that investors perceive poor quality reporting as increasing social and political cost exposures. Sustain Account Manag Policy J 10:208-234

Sarfaty GA (2013) Regulating through numbers: a case study of corporate sustainability reporting. Va J Int'1 L 53:575-622

Sarro D (2012) Do lenders make effective regulators? An assessment of the Equator Principles on project finance. German Law J 13:1525-1558

Schäfer H (2012) Sustainable finance. http://ssrn.com/abstract=2147590. Accessed 15 Nov 2021

Serafeim G (2018) Investors as stewards of the commons? Journal of Applied Corporate Finance 30:8-17. https://ssrn.com/abstract=3014952. Accessed 15 Nov 2021

Sheehy B (2021) Sustainability, justice and corporate law: redistributing corporate rights and duties to meet the challenge of sustainability. European Business Organization Law Review, this volume

Sjåfjell B, Rapp Nilsen H, Richardson BJ (2017) Investing in sustainability or feeding on stranded assets: the Norwegian Government Pension Fund Global. Wake Forest L Rev 52:949-979

Tadros H, Magnan M (2019) How does environmental performance map into environmental disclosure?: a look at underlying economic incentives and legitimacy aims. Sustain Account Manag Policy J 10:62-96

Taibi S, Antheaume N, Gibassier D (2020) Accounting for strong sustainability: an intervention-research based approach. Sustain Account Manag Policy J 11:1213-1243

Tan C (2019) Creative cocktails or toxic brews? Blended finance and the regulatory framework for sustainable development. In: Gammage C, Novitz T (eds) Sustainable trade, investment and finance: toward responsible and coherent regulatory frameworks. Edward Elgar, Cheltenham, ch 13

Tanzil D, Beloff BR (2006) Assessing impacts: overview of sustainability indicators and metrics. Environ Qual Manag 15:41-56

Thaler R, Sunstein C (2009) Nudge: improving decisions about health, wealth and happiness. Penguin

UK Green Finance Taskforce (2018) Accelerating green finance. https://assets.publishing.service.gov.uk/ government/uploads/system/uploads/attachment_data/file/703816/green-finance-taskforce-accelerati ng-green-finance-report.pdf. Accessed 15 Nov 2021 
UK Home Department (2019) Independent Review of the Modern Slavery Act 2015: Final Report. https:// assets.publishing.service.gov.uk/government/uploads/system/uploads/attachment_data/file/803406/ Independent_review_of_the_Modern_Slavery_Act_-_final_report.pdf. Accessed 15 Nov 2021

UNEP FI (2019) Fiduciary duty in the 21st century. https://www.unepfi.org/wordpress/wp-content/uploa ds/2019/10/Fiduciary-duty-21st-century-final-report.pdf. Accessed 15 Nov 2021

Vives A, Wadhwa B (2012) Sustainability indices in emerging markets: impact on responsible practices and financial market development. J Sustain Finance Invest 2:318-337

Walker J, Pekmezovic A, Walker G (2019) Sustainable development goals: harnessing business to achieve the SDGs through finance, technology, and law reform. John Wiley \& Sons, Chicester

Wins A, Zwergel B (2016) Comparing those who do, might and will not invest in sustainable funds: a survey among German retail fund investors. Bus Res 9:51-99

Yamahaki C (2019) Responsible investment and the institutional works of investor associations. J Sustain Finance Invest 9:162-181

Zetzsche DA, Anker-Sørensen L (2021) Regulating sustainable finance in the dark. European Business Organization Law Review, this volume

Publisher's Note Springer Nature remains neutral with regard to jurisdictional claims in published maps and institutional affiliations. 